\title{
Title: Unobtrusive Indicators of Culture for Organizations: A Systematic Review
}

Tom W Reader PhD*, Alex Gillespie PhD*, Julie Hald MSc*, Megan Patterson MSc*

* Department of Psychological and Behavioural Science, London School of Economics, Queens House, London, UK, WC2A 2AE

Emails: Tom Reader: t.w.reader@1se.ac.uk; Alex Gillespie: a.t.gillespie@1se.ac.uk; Julie Hald; E.J.Hald@1se.ac.uk; Meghan Patterson: pattermc@tcd.ie;

Address for correspondence: Dr Tom Reader, Department of Psychological and Behavioural Science, London School of Economics, Queens House, London, UK, WC2A 2AE. Phone +44 7955 7712; Fax +44 207955 7565; E-mail t.w.reader@1se.ac.uk

Acknowledgements: The study was supported by a research donation from the AKO Foundation, a charitable trust.

Disclosure statement: There are no current or potential conflicts of interest (i.e. financial interests) arising from this work.

Data: The data that support the findings of this study are available on request from the corresponding author

Keywords: Organizational culture; Unobtrusive data; Systematic review; Methodology; Data science 


\title{
Unobtrusive Indicators of Culture for Organizations: A Systematic Review
}

\begin{abstract}
We systematically reviewed the literature using unobtrusive measures to study organizational culture. To synthesize, theorize, and evaluate this research, we introduce the concept of an unobtrusive indicator of culture (UIC) for organizations. A UIC measures organizational culture through collecting data without engaging employees, and is conceptualized in terms of Schein's (1992) description of cultural artefacts. We identified thirty-five articles, containing 135 distinct UICs, drawn from 16 distinct data sources. UICs coalesced into two groups. First, textual UICs, with culture measured through language patterns in annual reports, employee online reviews, and emails. Second, UICs focusing on organizational practices, for instance organizational policies or executive rewards. Over twothirds $(68 \%)$ of UICs measured values for integrity, results orientation, and clan cultures, and we conjecture that UICs may be most useful for studying aspects of culture sensitive to reporting biases, and benchmarking large samples of organizations. Forty-eight percent of UICs had good or promising construct validity: many were textual UICs, and those focusing on organizational practices were less established. UICs can potentially advance the study of organizational culture, yet must be developed and applied cautiously, with careful consideration of their advantages and limitations, and how they complement existing measurements and conceptualizations of culture.
\end{abstract}

Keywords: Organizational culture; Unobtrusive data; Systematic review; Methodology; Data science 
Advances in data accessibility and data science mean that naturally occurring data, for instance collected from social media, institutional reports, or company websites, are increasingly used to investigate organizational culture (Knight, 2018; Tonidandel, King, \& Cortina, 2018). Organizational culture is described in terms of the shared values, beliefs, and norms that shape meaning and guide behavior (Chatman \& O'Reilly, 2016), and the advantages, limitations, and validity of methodologies using novel and often digital data to study culture have yet to be theorized or evaluated. To address this, we conceptualize the use of naturally occurring data to study organizational culture in terms of the unobtrusive measures literature: this refers to the practice of using non-reactive methods (i.e., gathering data without engaging participants) to study cognition and behavior (Webb, Campbell, Schwartz, \& Sechrest, 1966), and resonates with Schein's (1992) description of using cultural artefacts (e.g., language, procedures) to reveal organizational culture. We undertake a systematic review of studies using unobtrusive measures to investigate organizational culture, and assess the types, validity, and contribution of data sources and measurements used within the literature. To synthesize and evaluate this diverse body of research, we introduce the methodological construct of an unobtrusive indicator of culture (UIC) for organizations. A UIC refers to a single measure of organizational culture based on data collected without engaging employees. We examine the construct validity of UICs that have been used in unobtrusive investigations of organizational culture, consider the insights they can provide, and reflect on their challenges and development needs.

\section{Organizational culture}

Definitions of organizational culture vary according to academic discipline (Jung et al., 2009; Verbeke, Volgering, \& Hessels, 1998), and according to Giorgi et al (2015), at least five distinct conceptualizations of culture in organizational studies have emerged. These 
include a focus on i) the shared meanings and values that underpin culture and influence organizational practices (Barney, 1986; Cameron \& Quinn, 1999; Schein, 1999), ii) the transmission of ideas and construction of identity through culture (Levi-Strauss, 1979; Mitroff \& Kilmann, 1976), iii) the role of culture in determining how people direct attention and understand a situation (Rao \& Giorgi, 2006), iv) the influence of culture on how people derive meaning or take action (Bourdieu, 1990; Lamont \& Thevenot, 2000), and v) the role of culture as a system for defining and structuring the conceptual distinctions that support everyday sense-making (Hsu \& Hannan, 2005; Lakoff, 1987; Mervis \& Rosch, 1981).

Research on organizational culture has been profoundly shaped by Schein's (1984) seminal framework. This proposes three inter-related levels of organizational culture: artefacts, which are the rituals, language, systems, procedures, stories, and ergonomics of an organization; espoused values, which relate to the "strategies, goals, and philosophies (espoused justifications)" that guide behavior (Schein, 1999, p. 21); and underlying assumptions, which are the "unconscious, taken for granted beliefs, perceptions, thoughts, and feelings....(ultimate source of values and action)" that are non-debatable, and guide group member perceptions, thoughts, feelings and behavior (Schein, 1999, p. 21). Each level can be understood in terms of values that are commonly held within an organization, with artefacts being their manifestation in activity and outputs, espoused values their articulation by managers and employees, and underlying assumptions their influence on the assumed norms and implicit beliefs that guide action.

The values shared between organizational members, and communicated by organizational leadership, are often central to conceptualizations of organizational culture. For instance, organizational culture is described in relation to the: "the shared basic assumptions, values, and beliefs that characterize a setting and are taught to newcomers as the proper way to think and feel" (Schneider et al., 2013; p. 362); "the values, beliefs, and 
assumptions that are held by members of an organization and which facilitate shared meaning and guide behavior at varying levels of awareness" (Denison, Nieminen, \& Kotrba, 2014, p. 146); and the "system of shared values (that define what is important) and norms that define appropriate attitudes and behaviors for organizational members (how to feel and behave)" (O'Reilly and Chatman, 1996; p. 160). Leaders, through articulating and reinforcing the values they prioritise, are key influencers of organizational culture (Schein, 1992): for example, with leader values for self-direction being associated with innovative cultures (Berson, Oreg, \& Dvir, 2008), and leaders engaging in different forms of behavior (e.g., institution building, articulating a vision) to determine culture (Tsui, Zhang, Wang, Xin, \& $\mathrm{Wu}, 2006)$.

Research on organizational culture is often distinguished by whether it originates from qualitative and quantitative traditions (Morris, Leung, Ames, \& Lickel, 1999). Qualitative research, for example using ethnography, interviews, or case study analyses, has focussed on the implicit beliefs and assumptions that guide behavior, and how they materialize and are propagated in organizational processes, narratives, and practices. Quantitative research, mostly using surveys, has explored the espoused values and reported norms that determine behavior. Qualitative approaches focus on the unique cultural characteristics of a given institution, and how these occur in everyday life and shape meaning, whilst quantitative approaches tend to adopt a functionalist perspective whereby culture is theorized as a property that can be measured and benchmarked between organizations, and used to predict behavior and performance. In recent years, and due to the desire to develop robust and valid measurements that can be applied at scale and used across institutions, research has tended towards quantitative methods, with a range of surveys being developed and tested (Jung et al., 2009). Through surveys such as the organizational culture inventory (Cooke \& Szumal, 1993), Denison's organizational culture survey (Denison et al., 
2014), the competing values framework (CVF) (Cameron \& Quinn, 1999), and the organizational culture profile (OCP) (O'Reilly, Chatman, \& Caldwell, 1991), dimensions of culture that are common, important for performance, and comparable between organizations, have been outlined. Many culture surveys identify values for adaptability, performance, and supporting employees as core to organizational culture (Van den Berg \& Wilderom, 2004), with the consensus (e.g., between employees) and intensity of cultural values predicting behavior and outcomes (Boyce, Nieminen, Gillespie, Ryan, \& Denison, 2015; Chatman, Caldwell, O'Reilly, \& Doerr, 2014; Denison et al., 2014; Hartnell, Ou, \& Kinicki, 2011). Nonetheless, and despite the progress made, areas for development remain, particularly around more conclusively establishing the link between organizational culture and performance (Chatman \& O'Reilly, 2016). The relationship between organizational culture and climate has been of particular interest (Denison, 1996), with organizational climate defined as the "shared perceptions of and the meaning attached to the policies, practices, and procedures employees experience" (Schneider, Ehrhart, \& Macey, 2013, p. 362). Researchers have used climate surveys to study how employee perceptions of the organizational environment determine behavior (e.g., in relation to safety), and a continuing topic of interest is the relationship between climate and the systems of meaning, values, and norms that constitute culture (Ostroff, Kinicki, \& Muhammad, 2012). Furthermore, critical analyses of the field have argued that organizations rarely have a single culture, and are comprised of fragmented sub-cultures (Martin, 1992), for instance between teams. Indeed, the idea that culture can be measured as a unitary construct, and accurately described through participant responses that are themselves a product of culture and potentially influenced by a range of extraneous factors, has been questioned (McSweeney, 2002; Meek, 1988). Such insights resonate with qualitative theorizations of organizational culture, which despite being critiqued as fuzzy, non-generalizable, and not associable with outcomes (Jung et al., 2009; 
Morris et al., 1999), aim to provide concrete insight on how values and behaviors manifest within organizations so that theorizations of culture are anchored in observed reality rather than abstractions.

In recent years, a notable development in organizational culture research has been the trend of researchers using advances in data accessibility and data science to study organizational culture (Knight, 2018; Tonidandel et al., 2018). For instance, measuring organizational culture by analyzing the text contained in employee emails and activity on social media (e.g., for measuring values relating to goal-orientation) (Moniz, 2015; Srivastava, Goldberg, Manian, \& Potts, 2017), or through collecting data on institutional activities (e.g., policies, reward systems, and practices relating to corporate social responsibility) that reveal managerial values (e.g., towards work-life balance, rewarding performance, ethics) (Di Giuli \& Kostovetsky, 2014; Erwin, 2011; Hoi, Wu, \& Zhang, 2013). Such approaches appear consistent with Schein's (1999) description of artefacts, with culture being studied through naturally occurring language, practices, and organizational systems. Additionally, they may provide a means to combine the strengths of both qualitative and quantitative research on organizational culture. In domains such as political science, where the culture of governments is often studied through patterns of action (internal processes, policy pronouncements, engaging individuals), the use of artefacts is accepted (Putnam, Leonardi, \& Nanetti, 1994; Westrum, 2004). However, and as recognized by Schein (1999), investigating organizational culture through artefacts is problematic due to the challenges of establishing construct validity (e.g., determining the values indicated by an artefact), and conceptualizing how artefactual data complements existing measures and advances research. We address these issues through drawing on Webb and colleagues (1966) conceptualization of unobtrusive measures in psychology research. 


\section{Unobtrusive measures}

The term "unobtrusive measures" was coined by Webb and colleagues (1966) in their seminal book theorizing the value of using non-reactive methodologies - where data is collected and analyzed (e.g., speeches, reports, decisions) without engaging participants. The key benefit of unobtrusive measures is suggested to be that, compared to reactive methodologies where "the processes involved in measurement affect the value obtained for the variable" (Sechrest \& Phillips, 1979, p. 3), they can address issues such as social desirability and observer effects, increase measurement diversity and triangulation with selfreport data, and facilitate the study of phenomena not suited to surveys (Webb et al., 1966). Unobtrusive measures were initially suggested to be used in tandem with conventional (e.g., self-report) methodologies, but, in practice, have been recognized as difficult for researchers to operationalize (Webb \& Weick, 1979). However, recent developments in data accessibility (e.g., public databases) and data science (e.g., advanced textual analyzes, machine learning) (Luciano, Mathieu, Park, \& Tannenbaum, 2018; Short, McKenny, \& Reid, 2018; Tonidandel et al., 2018) have shown the prescience of Webb and colleagues (1966) ideas, with a literature revealing the promise and challenges of using unobtrusive measures emerging (Hill, White, \& Wallace, 2014).

Unobtrusive investigations in organizations have tended to rely on two forms of data: textual and behavioral (Hill et al., 2014). Textual data, which can be obtained on scale through transcripts, social media, company reports, and organizational websites, has been analyzed using natural language processing techniques (Short et al., 2018). Research shows that linguistic styles, for example using words associated with narcissism in speeches, are indicative of personality traits and decision-making style (Chatterjee \& Hambrick, 2007), that determining personality from text in social media has concurrent validity with surveys (Park et al., 2015), and that mission statements can be revealing of organizational strategic 
priorities (Short \& Palmer, 2008). Other data, drawn from electronic records, institutional processes, or organizational structures, have also been used: for example to study investment decisions (Campbell, Gallmeyer, Johnson, Rutherford, \& Stanley, 2011). Yet, although promising, a number of limitations in using unobtrusive measures have emerged, which have precluded their wider use. For example, measures often lack construct validity testing, impression management remains a problem (e.g., public speeches have an audience), and it is often not clear whether data (e.g., mission statements) are revealing of individual or group beliefs (Hill et al., 2014).

Through combining the ideas of Webb and colleagues (1996) and Schein (1999), a framework can be developed for understanding and evaluating the analysis of new, and often naturally occurring, data to investigate organizational culture. This is because the increasing use of textual and behavioral data to study culture is consistent with the conceptualization of unobtrusive measures, which in-turn, can be understood as the study of organizational culture through artefacts. The benefit of this unobtrusive approach to studying organizational culture is, potentially, the enabling of greater measurement diversity (i.e., through the study of a wider range of cultural phenomena), the facilitation of longitudinal research (e.g., through archive review), and the possibility for large-scale studies (e.g., across industries) that are difficult to achieve through surveys alone (e.g., due to access constraints). Additionally, through their combination with survey data, unobtrusive data may facilitate the investigation of Schein’s (1999) “underlying assumptions”, with disjunctions between espoused and enacted cultural practices being especially powerful for revealing institutional priorities (Kummerow \& Kirby, 2013; Ouchi \& Wilkins, 1985; Schein, 1984). Finally, unobtrusive measures might also allow for researchers to overcome response biases (e.g., due to impression management, pressure to respond positively, normalization of unusual practices) that can influence survey responses on culture (Bolino, Kacmar, Turnley, \& Gilstrap, 2008; 
McSweeney, 2002; Morrison \& Milliken, 2000, p. 706). This may be especially useful for overcoming the challenges of studying cultures with deep-set problems (Antonsen, 2009), for instance where unethical acts are incentivized and facilitated (Kulik, 2005; Leaver \& Reader, 2017), or risk-taking is normalized (Vaughan, 1999) and endemic within certain organizational functions (Paté-Cornell, 1993).

Yet, given the acknowledged limitations of using unobtrusive measures (Hill et al., 2014), and the challenges in discerning insight from artefacts due to their ambiguous nature (Schein, 1999, p. 21), the extent to which unobtrusive measures can provide valid and accurate information on organizational culture remains questionable. Unlike organizational culture surveys, through which construct validity is established by refining question items, factor analysis, sampling, and comparisons between instruments (Haynes, Richard, \& Kubany, 1995; Jung et al., 2009), the validity of using unobtrusive data to measure organizational culture is not determined. Currently, the literature is undefined, disparate and unassembled, with a diverse range of data sources and measurements, and the construct validity of measures not being evaluated. It is not apparent that unobtrusive measures can be used to study the shared values and beliefs that are integral to organizational culture (Chatman \& O'Reilly, 2016), or whether unobtrusive measures can be used to collect data on dimensions of values commonly identified as underpinning culture (Van den Berg \& Wilderom, 2004). Accordingly, it is not clear if the use of unobtrusive measures is a valid way to study organizational culture, whether some data sources and analytical approaches are more promising than others, or whether the findings of unobtrusive investigations of culture are similar and coherent to the existing literature.

To address the issues outlined above, and investigate both the construct validity and potential value of using unobtrusive measures to study organizational culture, we undertake a systematic review of the literature. Through identifying and reviewing unobtrusive 
investigations of organizational culture, we aim to assemble, conceptualize, operationalize, and critically evaluate the unobtrusive data sources and measurements used in studies of organizational culture.

\section{Unobtrusive indicators of culture for organizations: procedures for reviewing the}

\section{literature}

To review the literature using unobtrusive measures to study organizational culture, we introduce the methodological construct of an unobtrusive indicator of culture (UIC) for organizations. Reflecting Webb and colleagues (1966) description of an unobtrusive measure, a UIC refers to a single measure of organizational culture based on naturally occurring data collected without engaging employees. This reflects Schein's (1999) description of organizational artefacts, with analyzes of language, behaviors, systems, processes, and rituals within an organization being conceptualized to provide an indirect measure of the beliefs and values held by employees and managers.

Crucially, and as recognized by Schein (1999), the validity of using unobtrusive measures depends on the extent to which they can be evaluated and shown as having construct validity, and we propose the UIC construct in order to provide a framework against which unobtrusive measures of culture can be conceptualized, synthesized, and evaluated. Specifically, studies using unobtrusive measures to investigate organizational culture are challenging to review and collate due to them utilizing heterogeneous data sources (e.g., textual data, behavioral data), which are than subjected to further diverse analyses. To synthesize the literature, and assess the diverse range of unobtrusive measures within a consistent framework, we identify and evaluate the data sources that are used to investigate organizational culture, and the indicators that are drawn from them. This is because, akin to self-report measures, the quality and function of an unobtrusive measure may be a product of 
the methodology being used (i.e., data source), or the specific measurements that are taken (e.g., the focus of a measure). Thus, we use the UIC construct to evaluate the literature, and investigate the following issues.

First, we aim to identify the population of unobtrusive data sources and UICs used in organizational culture research. We identify organizational culture studies using unobtrusive methodologies and, for each, determine the data source used, the data points used, their scaling, and the aspect of culture being measured. Additionally, we classify data sources as internal (i.e., produced by an organization) or external (i.e., produced outside an organization) to determine their independence from organizations and thus impression management, and identify the organizational groups (e.g., management, all employees) UICs purport to represent. Through this process, we synthesize unobtrusive data sources, and consolidate their measurements into the UIC structure (data point, scaling, and cultural focus).

Second, and as part of the process of establishing construct validity for unobtrusive measures of culture, we evaluate the validity of UICs as cultural indicators. This relates to content validity, which is "the degree to which elements of an assessment instrument are relevant to and representative of the targeted construct for a particular assessment purpose" (Haynes et al., 1995; p. 238). For UICs to be valid cultural indicators, they should operationalize the definition of organizational culture. We build on the idea outlined by Schein (1999) that organizational artefacts potentially reveal the norms and values held by organizational members. Thus, drawing on definitions of organizational culture outlined in recent major papers (Chatman \& O’Reilly, 2016; Denison et al., 2014; Schneider et al., 2013), we consider the extent to which UICs provide potentially valid measures of the shared assumptions, values, and beliefs that characterize an organization and guide behavior.

We initially evaluate whether the aspects of culture measured by UICs can be interpreted within the framework of two established culture models: the OCP and the CVF. 
The purpose is to simultaneously provide an initial framework against which the UIC literature can be structured and understood, and to investigate whether UICs can be integrated into the established (and primarily survey-based) literature on organizational culture. First, we examine the consistency of UICs with the OCP, which measures and describe the norms and values that characterize an organizational culture, indicate priorities, and determine behavior. Factor analyses of surveys using the OCP identify six dimensions of culture common to different organizations: (Chatman et al., 2014; O'Reilly et al., 1991): i) adaptability; ii) collaboration; iii) customer orientation; iv) detail orientation; v) integrity; and vi) results orientation. Second, we consider UICs in relation to the CVF (Cameron \& Quinn, 1999), which applies a typological model, with two orthogonal dimensions of culture outlined (flexibility versus control, and internal versus external focus), and is used to describe four competing types of culture (clan, adhocracy, market, hierarchy). Although alternative models might have been used we utilize the OCP and CVF because of their well-researched psychometric properties (Chatman et al., 2014; Hartnell et al., 2011), wide usage and coverage of culture dimensions included in other models (Van den Berg \& Wilderom, 2004), and their distinct approaches (i.e., dimensional and typological) to conceptualizing organizational culture. UICs not consistent with either the OCP or CVF will be thematically analyzed, in reference to the literature (Jung et al., 2009).

Next, and to determine their validity as cultural indicators, we evaluate whether the UICs measure shared values in relation to their proposed OCP or CVF dimension. As previously discussed, although models vary, conceptualizations of organizational culture often place shared values at their core, and a measure of content validity is whether UICs provide insight on the shared values experienced or prioritized by an organizational group (e.g., team, entire workforce). For instance, employee reports on social media about experiences of job performance might reveal values across an organization towards 
achievement (Moniz, 2015), and the design of managerial incentive systems potentially reveal managerial values towards rewarding performance (Davidson, Dey, \& Smith, 2015). Conversely, if UICs only reflect the activity or thoughts of a single person, or cannot be associated with an organizational group, they may not be valid cultural indicators.

Third, for evaluating the level of construct validity of those UICs considered to be valid cultural indicators, we examine data on measurement validity (e.g., discriminant validity, convergent validity) and criterion validity (associations with organizational outcome data). We identify UICs that appear to have good construct validity, and those that require further development. Additionally, and through this process, we examine whether, based on the analysis of UIC construct validity, some unobtrusive data sources appear more promising for investigating organizational culture. Finally, through determining whether UICs with good or promising construct validity focus on particular cultural dimensions, we consider the dimensions of organizational culture that UICs might be most useful for investigating.

\section{Method}

\section{Study identification}

Studies were identified through four stages (see Figure 1).

\section{INSERT FIGURE 1 HERE}

First, using the PsychINFO and Web of Science databases, articles investigating organizational culture were identified by a team of three MSc-level research assistants. Search terms were modeled on those used to describe the field of organizational culture in a previous literature review (Schneider et al., 2013). There was no search start date, and an end 
date of December 31, 2017. Key information on the articles (e.g., authors, titles, abstracts) were downloaded and compiled into a Microsoft Excel spreadsheet. In total, 3,184 unique articles were identified.

Second, the title and abstract of each article was screened by the three MSc-level research assistants, who each reviewed approximately one third of the identified articles. The purpose of screening was to identify articles reporting either empirical data or methodologies (e.g., indicated by the reporting of research findings, or use/testing of surveys, interviews, or focus groups) for investigating culture. Articles were removed if these features were not present (e.g., in editorials, conceptual articles, reflective works, those not studying culture). Where coders were unsure as to whether the exclusion/inclusion criteria were met, they downloaded the article and read it in full. This process led to 1,124 articles being removed

Third, the three reviewers each categorized one third of the remaining 2,060 articles in order to identify those using both "internal" (produced within an organization) and "reactive" (i.e., methodologies that involve directly engaging participants) data. Examples included surveys with employees, or interviews/focus groups with senior managers. To ensure accuracy of coding, random samples of the included/excluded articles were evaluated by a second coder and/or the lead author. Furthermore, cases where there was uncertainty in coding were discussed with the research team, with a majority decision being taken to decide article inclusion/exclusion. In total, 1882 articles were removed, and of these, 1,043 articles used surveys and 528 interviews with employees/managers.

Finally, of the 178 articles remaining, these were read by the lead author. Articles were marked for inclusion if they reported empirical data from an unobtrusive data source, and clearly reported (i.e., described) the measurement of organizational culture. The proposed list of articles marked for inclusion were considered by the research team (including two 
established psychologists), with uncertainty or disagreement being resolved through group discussion.

\section{Data extraction and analysis}

In order to identify and evaluate the UICs contained within the articles retrieved through the study identification process, data were extracted and categorized (see table 1) from each article through seven steps. These are described below:

\section{INSERT TABLE 1 HERE}

Step 1: Descriptive data. These included (1) authors, (2) year published, (3) country, (4) industry type, and (5) culture model investigated.

Step 2: Unobtrusive data sources. These were identified for each study.

Step 3: Identifying UICs. The specific data points used, and the indications of culture they provided, were extracted for each unobtrusive data source in each article. A single coder extracted the data, which were checked by a second coder. A descriptor for each UIC was written, and to ensure consistency, each was phrased in the positive. Additionally, if available, information was recorded on why an unobtrusive measures was used.

Step 4: Data production. UICs were classified as being produced internally (e.g., a company report) or externally (e.g., social media), and in terms of the organizational group being measured (e.g., managers, employees).

Step 5: Cultural dimension measured. UICs were evaluated in terms of whether they measured content relating to the OCP and CVF (see Table 1). Taking into account the UIC descriptors, and their originating articles (i.e., the culture models they examine), each UIC was classified in terms of consistency with the six-dimension OCP model (Chatman et 
al., 2014; O'Reilly et al., 1991): i) adaptability; ii) collaboration; iii) customer orientation; iv) detail orientation; v) integrity; and vi) results orientation. Then, UICs were classified in terms of the four culture types described within the CVF model (Cameron \& Quinn, 1999): clan; adhocracy; market; and hierarchy. UICs that did not fit with the OCP or CVF were inductively interpreted, using Jung and colleague's (2009) review of the common dimensions measured using organizational culture tools as a guidance.

Step 6: Validity as cultural indicators. Each UIC was then assessed in terms of whether it indicated shared values for its ascribed culture dimension. UICs were deemed a valid indicator of culture if they were the product of a clearly defined group (e.g., senior executives writing about innovation), a large and representative group (e.g., a large number of online reviews by employees), or represented a consensus of values (e.g., a formally agreed vision statement produced by stakeholders across an organization). UICs were deemed an invalid indicator of culture if it was unclear who produced the UIC (e.g., litigation cases), difficult to distinguish culture from outcomes (e.g., performance data), measures focused on data points reflecting external factors rather than values within an organization (e.g., different regulatory systems), or if data may be explained by other factors (e.g., writing style, where grammatical structure is used as an indicator of culture).

Step 7: Construct validity. UICs evaluated as not being a valid cultural indicator were automatically determined as lacking construct validity (i.e., because they did not indicate culture). For UICs classified as valid cultural indicators, construct validity was determined through assessing them in terms of whether data was reported on the properties of the measurements being used (e.g., reliability, discriminant validity, convergent validity), and whether criterion validity was tested and shown (i.e., using an independent form of outcome data). UICs assessed as being valid cultural indicators (i.e., indicating shared values), but with no further information on measurement properties or criterion validity were evaluated as 
having low construct validity. Those with data showing either good measurement properties or criterion validity were evaluated as having promising construct validity. Finally, UICs with data establishing good measurement properties and criterion validity were evaluated as having good construct validity.

Figure 2 summarizes the codification process, and provides examples for the evaluation of UICs generated from distinct data sources, relating to different dimensions of organizational culture, and with variable levels of construct validity. For stages 1-4 and 7, which involved extracting and classifying information within the article (e.g., significant associations with outcomes), categorizations were checked independently for coding errors by a second reviewer. For stages 5-6, which focused on applying externally derived (to the articles) models of culture to interpret UICs, and then evaluating them as valid indicators of culture (conceptualized as shared values), assessments were conducted independently by two organizational psychologists. Intra-class correlations (ICC) were calculated to check the reliability of assessments. Where coders agreed on the classification these were assigned, and where they did not agree (e.g., one coder assessed a UIC as relating to results orientation, and the other customer orientation), a third psychologist evaluated the UIC. This involved inspecting the codes of the two independent coders (anonymously listed, to avoid bias), and then assigning the code, with a written justification, they thought best fit the UIC. In all cases, the third coder agreed with one of the other coders, and this code was applied.

INSERT FIGURE 2 HERE

\section{Results}

\section{Population of data sources and UICs used to investigate organizational culture}


Identified through steps 1-3, thirty-five articles (Table 2) reporting 135 UICs and 16 distinct unobtrusive data sources were specified. This equates to $1.7 \%$ of empirical articles identified, with 63\% published since 2010, and two citing Webb et al. (1966). Annual reports were the most commonly used unobtrusive data source (seven articles), followed by industry data (six articles), employee online assessments (five articles), policies/code of conduct (five articles), and executive analytics (five articles).

\section{INSERT TABLE 2 HERE}

The full set of 135 UICs and underlying papers is available in an online supplementary file. Table 3 lists the different unobtrusive data sources used to study organizational culture, and reports on their key features (e.g., the conceptual model used), and the number of UICs generated for each.

\section{INSERT TABLE 3 HERE}

In terms of the number of UICs reported in each paper, this varied from one UIC (Tate \& Yang, 2015) to as many as 12 (drawn from different data sources) (Dobbin, Kim, \& Kalev, 2011). Twenty-two distinct models of culture were investigated in the articles. UICs were used to study ethical organizational cultures (four articles), cultures of social responsibility (three articles), the OCP (three articles), gendered organizational culture (two articles), organizational culture fit (two articles), customer orientation (two articles), and more generic models (four articles). Rationales for using unobtrusive measures varied, and included collecting data on hard-to-access companies and samples, gathering data on institutional practices complex to study through surveys (e.g., ethics, bullying, collaboration), 
and evaluating cultural practices through the perspective of those who encounter them (e.g., customers) (Biggerstaff, Cicero, \& Puckett, 2015; Davidson et al., 2015; Deshpandé, Farley, \& Webster Jr, 1993; Ji, Rozenbaum, \& Welch, 2017; Moniz, 2015). Step 4 of the analysis found 69 UICs to use externally generated data (51\%), and the majority of UICs to focus on managerial values $(67 \%)$.

Data sources, and their underlying UICs, formed into two substantive groups. First, UICs using analyzes of textual data, for instance drawn from employee online assessments and annual reports, conceptualized culture as being revealed through references by employees and management to words related to aspects of organizational culture (e.g., results orientation). Employee online assessments were analyzed to reveal employee values across an entire institution, and annual reports were analyzed to study the values of senior managers who lead companies. Second, UICs analyzing practices, for instance studied through data sources such as executive analytics, organizational policies, industry data, and financial data were used to study the organizational values held by management or people across an organization. Practices, such as the structure of reward systems, were assumed to reveal managerial priorities. Various miscellaneous UICs were also found. These included the analysis of customer surveys and observations from industry experts, who were assumed to provide insight on an entire culture (e.g., towards customer orientation) (Deshpandé et al., 1993; Williams \& Attaway, 1996), non-expert (e.g., student) evaluations of organizational websites to determine managerial and content provider values (e.g., on the importance of diversity) (Braddy, Meade, \& Kroustalis, 2006), the analysis of images held in annual reports to reveal managerial assumptions (e.g., on gender) (Mills, 2005), and the use of aggregated company rating scores on employee online reviews (Ji et al., 2017).

\section{Validity as cultural indicators}


Step 5 of the analysis found 96 UICs to be consistent with the six-dimension OCP model, and 77 consistent with the four typologies within the CVF. There was, respectively, $93 \%$ agreement $($ ICC $=.828$ : indicating good reliability) and $89 \%$ agreement $($ ICC $=.729$ : indicating good reliability) between two coders for categorizing UICs in terms of the OCP and CVF. In total, 55 UICs were found to be coded in terms of dimensions for both models, with the concepts of adaptability/adhocracy, collaboration/clan, customer orientation/market, and results orientation/market overlapping. Of the remaining 82 UICs, 41 were coded as relating only to the OCP (primarily for the dimension of integrity), and 22 to the CVF (primarily for "clan" cultures). Seventeen UICs could not be classified using either the OCP or CVF, and these were inductively grouped together under the dimension of "diversity", as they related to prejudice and equality, which is not clearly conceptualized within the OCP or CVF. For step 6 of the analysis, 81 UICs (87\% agreement, ICC $=.747$, indicating good reliability) were evaluated as valid cultural indicators (i.e., indicating shared values for a group or entire organization). We provide a summary of the results for steps 5 and 6 below, and in Table 4.

\section{INSERT TABLE 4 HERE}

The largest group of UICs pertained to integrity $(n=38,28 \%)$, of which many were drawn from executive analytics $(n=13)$ and policies/code of conduct $(n=8)$. Sixteen $(42 \%)$ of the integrity UICs had validity as cultural indicators, including executive analytics UICs (e.g., quality of internal financial controls) revealing the importance placed by senior management on ethical conduct (Biggerstaff et al., 2015; Davidson et al., 2015; Huang et al., 2015), and industry data (e.g., on company CSR activities) indicating values of organizational management towards ethics (Di Giuli \& Kostovetsky, 2014; Erwin, 2011; Hoi et al., 2013). 
UICs using employee online assessments analyzed language to capture employee perceptions and experiences of integrity within a company (Popadak, 2013), and those drawing on annual reports indicated, through references to ethics and integrity, the importance of these constructs to management (Ankney \& Procopio, 2003; Erwin, 2011; Loomis \& Meyer, 2000). UICs lacking validity as cultural indicators included those using executive analytic data to measure political affiliations (which may be independent of culture) (Di Giuli \& Kostovetsky, 2014), legal data (which may reflect the values of litigants) (Hutton, Jiang, \& Kumar, 2015), and the tone of documents (which may indicate writing style rather than shared values) (H. Farrell \& Farrell, 1998).

The second largest cluster of UICs related to collaboration/clan $(n=17)$ or clan $(n=17)$. Of these UICs, approximately two thirds had validity as cultural indicators, with the greatest number of UICs being drawn from employee online ratings comments $(n=12)$. UICs were drawn from rating scores and textual analyzes (e.g., references to collaboration, or being supported by employers) of employee online assessments (Huang et al., 2015; Ji et al., 2017; Moniz, 2015; Popadak, 2013). Similarly, textual references (e.g., to teamwork, or valuing employees) in annual reports (Daly, Pouder, \& Kabanoff, 2004; Fiordelisi \& Ricci, 2014; Mescher et al., 2010), mission statements (Swales \& Rogers, 1995), and organizational websites (Braddy et al., 2006) were analyzed to reveal managerial values towards collaboration or affiliation with employees. Alternative UICs included industry experts rating companies on supporting staff (Kowalczyk \& Pawlish, 2002), or analyzes of policies (e.g., on work-life balance) indicative of managers supporting their employees (Ball, Monaco, Schmeling, Schartz, \& Blanck, 2005; Dobbin et al., 2011). UICs lacking validity focused on leadership rather than culture (Huang et al., 2015; Ji et al., 2017), family characteristics rather than values (Huang et al., 2015), or comprehensibility of workplace contracts, which may reflect writing style rather than values (Suchan \& Scott, 1986). 
A substantial group of UICs $(n=20)$ also related to results orientation/market and results orientation/hierarchy. Nineteen of these had validity as cultural indicators, and were mostly drawn from employee online/ratings, annual reports, and organizational websites. Analyses of online employee assessments captured perceptions and experiences of values relating to performance (Huang et al., 2015; Moniz, 2015; Popadak, 2013), and textual analyses of annual reports (Daly et al., 2004; Fiordelisi \& Ricci, 2014; Suzuki, 2013) and organizational websites (Braddy et al., 2006) indicated managerial prioritization of results. Somewhat related to these UICs, there were the nine customer orientation/market UICs, of which only three were considered to have validity as cultural indicators: for instance customer evaluations of customer-orientation (Deshpandé et al., 1993; Williams \& Attaway, 1996). Other UICs focused on performance for supporting service users (Sullivan et al., 2013), and these may reflect competencies rather than values. A handful of UICs related to adaptability/adhocracy $(n=5)$ and detail orientation $(n=3)$, all of which had validity as cultural indicators, for instance references to innovation in company reports (Chatman et al., 2014; Fiordelisi \& Ricci, 2014), or detail orientation in employee online reviews (Popadak, 2013).

Finally, seventeen UICs related to diversity, with under half $(n=8)$ having validity as cultural indicators. For example, UICs analyzing websites and documents for organizational policies on supporting disabled or minority employees indicated managerial values towards diversity (Braddy et al., 2006; Wilson, 2000). However, many UICs, such as those focusing on employee records (e.g., workplace demographics) (Ankney \& Procopio, 2003; A. Farrell, 2015) or discrimination litigation (Dobbin et al., 2011), were considered to reflect other factors (e.g., industry characteristics) than organizational culture.

\section{Construct validity}


Stage 7 found that of the 81 UICs considered to have validity as cultural indicators (a feature of content validity), 12 had good construct validity (i.e., data showing measurement and criterion validity), and these related to results orientation/market $(n=4)$, collaboration/clan $(n=4)$, clan $(n=3)$, and customer orientation/market $(n=1)$. Fifty-two UICs had promising validity (i.e., with either measurement or criterion validity), and the largest group pertained to integrity $(n=14)$ and results/market $(n=9)$. It was notable that, of the data sources, employee online assessments, annual reports, and emails accounted for approximately $48 \%(n=31)$ of the UICs with good or promising construct validity, with this constituting $82 \%$ of UICs drawn from these data sources. UICs drawn from policies/code of conduct, executive analytics, organizational website, and industry expert surveys constituted the bulk of non-textual UICs. Seventeen UICs had low validity, with those pertaining to diversity being the largest group $(n=7)$.

In terms of UICs with good construct validity, examples are reported in table 5, and a variety of observations on the relationship between UICs and organizational outcomes were observed. In relation to results orientation/market, and validated through principle component analysis and topic modelling algorithms, language relating to results in 1.8 million employee reviews (across 4,673 firm-year observations) was associated with short-term increases and long-term firm value decreases (Popadak, 2013), and language relating to goal orientation (measured using over 400,000 reviews) was associated with higher future earnings for firms $(\mathrm{p}<.001)($ Moniz, 2015). For clan/collaboration, employee-culture fit (measured through email communications, and tested through linguistic analyses) was associated with employee performance ratings (Goldberg, Srivastava, Manian, Monroe, \& Potts, 2016) and involuntary exit (Srivastava et al., 2017). References to competition and concern for employees in the annual reports of merging companies $(\mathrm{n}=59)$ were evaluated through cluster analysis, and found to positively associate $(\mathrm{p}<.01)$ with post-acquisition performance (Daly et al., 2004). 


\section{INSERT TABLE 5.}

Of the UICs with promising construct validity (see table 6 for examples), many drew on analyses of language $(n=15)$, yet did not establish criterion validity or test the structure of linguistic measurements. Other promising UICs focused on organizational practices, and these broke into two groups. For some UICs, for example analyses of the content of websites (e.g., in relation to innovation) (Braddy et al., 2006), policies relating to ethics (Erwin, 2011), or policies to support diversity (Dobbin et al., 2011), measurements were assessed using convergent validity, conceptual rating exercises or reliability coding, but with no outcome data being captured. For other UICs, for instance those using internal financial controls to investigate ethical culture (Davidson et al., 2015), or compensation schemes to study values for performance (Huang et al., 2015), measurements were not assessed, however associations with outcome data were observed (e.g., misstated financial data, ROA).

\section{INSERT TABLE 6.}

Finally, seventeen UICs were found to have low construct validity due to minimal information being available on the validity of measurements or their association with outcomes. Examples are provided in table 7, alongside potential suggestions for how these UICs might be developed to establish construct validity.

INSERT TABLE 7.

\section{Discussion}


A small, but expanding, literature has used unobtrusive measures to investigate organizational culture. In the 35 papers reviewed, 16 different sources of unobtrusive data were used, with 135 distinct UICs reported. The majority (22/35) of articles were published since 2010, and many drew on new digital sources. Nearly two thirds of UICs were evaluated as valid cultural indicators (i.e., they measured shared values), over a third had promising construct validity (i.e., evidence of measurement or criterion validity), and $9 \%$ had good construct validity (i.e., evidence of measurement and criterion validity). Forty-one percent of UICs were evaluated as not being valid cultural indicators - essential for content validity and focused on variables such as leadership, outcomes, demographics, and other miscellaneous factors (e.g., legal systems). Broadly, it was found the UICs could be distinguished into two distinct types.

The first group of UICs were drawn from analyses of the textual data contained in unobtrusive sources such as employee online assessments, annual reports, and employee emails. These UICs often emulated the survey literature, with latent dimensions (e.g., integrity) being revealed through language patterns related to that dimension (e.g., presence of words relating to transparency), and measured through their comparable intensity (use of words relating to ethics) between companies and groups. The benefits of using naturally occurring textual data to study organizational culture are that cultural values can be clearly operationalized (e.g., using dictionaries that represent a cultural dimension), data can be collected on a large scale (e.g., annual reports, which contain thousands of words, exist for most publicly listed companies) and analyzed longitudinally, with insights on different perspectives being available (e.g., managers and employees). UICs drawn from textual sources generally had good psychometric data (e.g., established through cluster analyses) and sometimes predicted outcomes (e.g., Tobin's Q, return on assets) (Moniz, 2015; Popadak, 2013; Srivastava et al., 2017). 
The second group of UICs, which tended to have low or promising construct validity, drew on data that captured organizational practices, for instance on corporate social responsibility, websites, executive decision-making, and organizational policies. UICs from these data sources were often assumed to reveal the values of management: for example, social responsibility initiatives and the design of executive reward systems were assumed to reveal the importance of integrity and results orientation respectively, and resonating with upper-echelons theory, influence the priorities and behaviors of employees (Carpenter, Geletkanycz, \& Sanders, 2004). However, in general, UICs measuring organizational practices had low or promising construct validity, with a common limitation being a lack of evaluation for the group or dimension of culture being measured, although associations with organizational performance were observed (Davidson et al., 2015; Huang et al., 2015). For UICs lacking validity as indicators of culture, it was often unclear what or whose values they represented, and examples include UICs focusing on shareholder political affiliation, presence of founding family executive members, or the number of promotion guidelines (Dobbin et al., 2011; Huang et al., 2015; Hutton et al., 2015).

Thus, and going forward, we consider UICs using analyzes of naturally emerging textual data from organizations and their members to be highly promising. However, questions remain on how best to utilize and theorize UICs drawn from these data. A key concern relates to the common practice of measuring culture through the presence of words relating to a dimension. For instance, management may refer to adaptability in an annual report to reveal aspirational rather than actual values (i.e., addressing concerns on innovation), and employees may refer to ethics in online reviews to report both positive (e.g., good ethical conduct) and negative experiences (e.g., fraud, risk-taking). Without some contextualization, which could be achieved through using the structure of data sources (e.g., comparing text in the "pros" and "cons" sections of employee online reviews) or aspect based 
sentiment analysis (where the positivity or negativity of words surrounding a target word is calculated), it is not clear whether language intensity towards a cultural dimension reveals a strength or weakness, or variation in uniformity of experiences (e.g., between employees) (Thelwall \& Buckley, 2013). Furthermore, as exemplified by research using language to explore cultural adaptation (Srivastava et al., 2017), further UICs might be developed to focus on the concrete practices that underpin a culture, and specified to particular groups. For example, through measuring references (by management) to performance targets in the annual report, or specific reports of mis-conduct amongst front-line staff. This would not only provide insight on cultural values (e.g., towards results orientation, ethics), but could be used to measure the practices that are used to instantiate culture (e.g., setting targets, unethical acts).

Substantial development is required for the use of non-textual UICs focusing on organizational practices. Conceptually, UICs measuring organizational practices are challenging to fit with the existing organizational culture literature, because although they do fit with Schein's (1999) description of artefacts, the extent to which they indicate shared values or provide data on organizational groups is debatable. Construct validity might be achieved through the use of content validity assessments (e.g., expert panels agreeing on the values underlying a UIC), further research on individual UICs (e.g., factors influencing a reward system), or testing convergent validity (e.g., with other UICs, surveys). A number of other miscellaneous UICs were identified, for example customer surveys or employee rating scores of their company, and these were generally found to be quite generic in nature (e.g., rating an organization as good or poor), and to provide little additional concrete information on organizational culture.

Finally, in terms of the content measured through UICs, the vast majority were classified using either the OCP or CVF, indicating that, despite their diverse origins, UICs 
can be interpreted and synthesized within existing frameworks of organizational culture. UICs relating to integrity, results/market, and clan constituted over half of all UICs, and approximately two thirds of the UICs with good or promising construct validity. The reasons for this coalescence did not emerge from the individual articles, and we conjecture that they may indicate that UICs are useful for studying aspects of organizational culture more influenced by reporting biases (e.g., surveys on values for integrity), and longitudinally benchmarking culture across many organizations in order to study the relationship with performance (i.e., where research is constrained by access or resource limitations). However, the advantages and disadvantages of UICs - in comparison to self-report measures - for studying these aspects of organizational culture remains undetermined and should be the subject of future research.

\section{Considerations}

The finding that UICs tend to focus on either language and organizational practices mirrors the broader field of unobtrusive research in organizations, which can be largely distinguished between language-based and behavioral-based research paradigms (Hill et al., 2014). For both paradigms to substantively contribute to the organizational culture literature, a range of methodological and theoretical issues require consideration.

First, and reflecting the increasing use of unobtrusive measures and data science in psychology research (Knight, 2018), the potential for developing new UICs or refining existing ones will likely increase, and following the development of unobtrusive measures more generally (Hill et al., 2014), ensuring new UICs meet a minimum standard of construct validity is needed. Additional sources of unobtrusive data could include media coverage, customer reviews, complaints, regulator audits, earnings call transcripts, or press releases. Analyses will increasing draw on technological advances, for example in natural language 
processing and machine learning (Yarkoni \& Westfall, 2017). Ideally, new UICs should be quantitatively scalable (to test for validity), automatable (to facilitate reproducible large-scale analysis), not easily manipulated (to remain non-reactive), and designed, with face validity, to indicate a dimension of organizational culture (e.g., integrity) for a clearly defined referent group. The organizational group examined is especially important to consider, because UICs that focus on small groups - usually top management - assume managerial values to represent an organization (yet, they may not), and those that focus on an entire organization (e.g., through measuring employee online reviews) do not focus on or recognize the subgroups that often exist within an organizational culture (Hofstede, Neuijen, Ohayv, \& Sanders, 1990). Yet, establishing whether culture data (e.g., managerial data) represents an entire organization, or pertains to specific sub-groups, would appear important for ensuring data is interpreted correctly. Additionally, although very few studies drew on multiple data sources to investigate organizational culture, this may be beneficial for testing convergent validity, and revealing points of tension within an organization (e.g., divergences between surveys and unobtrusive data, or between management and employees).

Second, where researchers do utilize UICs, it is necessary to be clear on the reasons for doing so, and the advantages and limitations of the data source being utilized. The review found that UICs coalesced around the dimensions of integrity, results orientation, and clan. The reasons for this were unclear, and we surmise that UICs may be useful for providing supplementary data on cultural practices that are subjective (e.g., unethical acts, risk-taking) and complex to study through self-report alone (Zuber \& Kaptein, 2014). Unobtrusive measures may also be useful for gaining access to organizations, for instance where researchers have limited resources, cannot enter an organization, or wish to benchmark culture across an industry (Chatman et al., 2014; Moniz, 2015). However, in using unobtrusive data to study organizational culture, the advantages and disadvantages of using 
specific data sources should be considered. For example, the benefit of using internal data such as an annual report is that it reveals the priorities of management, which can be difficult to access and measure through surveys. Yet, because annual reports are written for investors, they are highly influenced by impression management. Alternatively, external data such as from employee on-line reviews or customers surveys can provide an unvarnished and bottomup description of the culture, yet may be overly biased towards disgruntled employees, can be manipulated, and may reflect stereotypes (e.g., based on brand familiarity) rather than actual practices.

Third, unobtrusive data sources were initially conceptualized as organizational artefacts due to them capturing the language, behaviors, systems, processes, and rituals within an organization that are considered to be a product of, and therefore indicative of, organizational culture (Bonavia, 2006; Schein, 1999; Schneider et al., 2013). Yet, the content of the UICs reveal that unobtrusive data sources can operate at the boundaries between levels within Schein's model. For instance, within an annual report, which is a product of organizational management, managers clearly espouse their values (e.g., for diversity), and within employee online reviews, which are a record of employee experiences within a company, underlying beliefs and concrete examples of institutional culture are revealed (e.g., on the importance of training to an organization). The extent to which these data sources fit cleanly with the levels of Schein's model (1999), and thus can be used to explore it, partly depends on the UIC being derived (e.g., focusing on implicit references, reported behaviors, or direct statements relating to results orientation in employee online reviews). This indicates that where organizational culture is studied through UICs rather than self-report data, the distinctions between levels of culture are somewhat permeable, and potentially all can be observed. Indeed, to reflect this permeability, and rather than theorizing UICs as artefacts, future work may utilize more qualitative theorizations, for instance social constructionist 
perspectives that emphasize the practices that create, structure, and reinforce shared values (Berger \& Luckmann, 1991; Eliasoph \& Lichterman, 2003; Kotrba et al., 2012).

Fourth, UICs may have implications for practice and policy, and consideration is required for how they supplement existing self-report methodologies. For example, in industries where regulators attempt to monitor and manage organizational culture (Financial Conduct Authority., 2018), UICs represent an alternative and cost effective route through which to specify and monitor organizational culture (e.g., to identify organizations of concern) and enable inter-organizational learning. Organizations might use UICs to augment employee surveys, for example, comparing survey responses to relevant UICs, and investors might consider using UICs to benchmark the culture of an industry and identify companies with desired values and practices. Indeed, because surveys can be used to more precisely sample employees across an organization (e.g., in sub-groups, units), and measure values directly, they remain essential to culture measurement, and UICs are not a replacement.

Finally, consideration must be given to the ethical implications of using UICs to measure organizational culture. Studies in the review generally did not consider ethics, and due to the nature of the data, they rarely obtained informed consent from individuals or organizations due to the public nature of data. Yet, and in the context of controversies on using electronic data from people who have not given consent to participate in psychology studies (Gleibs, 2017), care must be taken to ensure unobtrusive data is treated respectfully, and in a way that does not breach anonymity.

\section{Limitations}

In terms of the process we have used to generate and review UICs, there are limitations. Relevant articles may have been excluded, and those included varied in content, focus, methodologies, and outcome variables, which rendered meta-analysis infeasible. Our 
initial focus on reports of identifying empirical studies of culture in titles and abstracts may have led to articles being excluded. Although we developed clear criteria for screening and including/excluding articles, and undertook various spot-checks, double coding, and group discussions (e.g., for resolving borderline-decisions) to ensure a robust final sample of papers, studies may have been overlooked or mis-coded. The coding of UICs relied on evaluations from three raters, and alternative perspectives may have led to different conclusions on construct validity and the values being measured by UICs. Our classifications were a first step in evaluating the validity of UICs: future work should use primary data.

Additionally, our analysis of UICs was limited to the OCP and CVF, and other general and specific (e.g., safety culture, ethical) models of culture may be equally relevant for interpreting the UICs. Also, our investigation into the validity of UICs as cultural indicators utilized the conceptualization of organizational culture as shared value systems. Whilst this provides insight on the content validity of UICs, further analyses are required (e.g., on the coverage and specific aspects of cultural practices investigated), and in the light of the many different conceptualizations of organizational culture (Giorgi, Lockwood, \& Glynn, 2015), and the heterogeneous nature of the data, other approaches could be applied.

\section{Conclusions}

This review found a small but growing literature utilizing UICs to measure organizational culture. However, their construct validity varied substantially. In general, UICs drawn from large-scale textual data (e.g., annual reports, employee online reviews) had good or promising construct validity. This is because these UICs, due to drawing on a large volume of text from multiple people, most clearly represented widespread values in an organization. UICs focusing on practices (e.g., executive analytics, organizational policies) tended to have no, low, or promising construct validity, and due to this, and their relatively 
narrow focus, appear more challenging to develop and integrate into the organizational culture literature, and may be more useful for converging with data from other sources. Cultural dimensions commonly measured by UICs were integrity, results orientation/market, and clan. The growing accessibility of digital data will increase the range of data sources that can be used to unobtrusively study organizational culture. Yet, the value and contribution of new UICs to the literature is contingent on ensuring they have construct validity, and can be embedded into existing conceptualizations of organizational culture. 


\section{References}

Ankney, R. N., \& Procopio, D. A. (2003). Corporate culture, minority hiring, and newspaper coverage of affirmative action. Howard Journal of Communication, 14(3), 159-176. http://dx.doi:10.1080/10646170304278

Antonsen, S. (2009). Safety culture assessment: A mission impossible? Journal of Contingencies and Crisis Management, 17(4), 242-254. http://dx.doi:10.1111/j.1468-5973.2009.00585.x

Ball, P., Monaco, G., Schmeling, J., Schartz, H., \& Blanck, P. (2005). Disability as diversity in Fortune 100 companies. Behavoural Sciences \& the Law, 23(1), 97-121. http://dx.doi:10.1002/bsl.629

Barney, J. B. (1986). Organizational culture: can it be a source of sustained competitive advantage? Academy of Management Review, 11(3), 656-665. http://dx.doi:10.5465/amr.1986.4306261

Berger, P. L., \& Luckmann, T. (1991). The social construction of reality: A treatise in the sociology of knowledge. UK: Penguin.

Berson, Y., Oreg, S., \& Dvir, T. (2008). CEO values, organizational culture and firm outcomes. Journal of Organizational Behavior, 29(5), 615-633. http://dx.doi: 10.1002/job.499

Biggerstaff, L., Cicero, D. C., \& Puckett, A. (2015). Suspect CEOs, unethical culture, and corporate misbehavior. Journal of Financial Economics, 117(1), 98-121. http://dx.doi:10.2139/ssrn.2285785

Bolino, M. C., Kacmar, K. M., Turnley, W. H., \& Gilstrap, J. B. (2008). A multi-level review of impression management motives and behaviors. Journal of Management, 34(6), 1080-1109. http://dx.doi:10.1177/0149206308324325

Bonavia, T. (2006). Preliminary organizational culture scale focused on artifacts. Psychological Reports, 99(3), 671-674. http://dx.doi:10.2466/PR0.99.3.671-674

Bourdieu, P. (1990). The logic of practice. Stanford, CA: Stanford University Press.

Boyce, A. S., Nieminen, L. R., Gillespie, M. A., Ryan, A. M., \& Denison, D. (2015). Which comes first, organizational culture or performance? A longitudinal study of causal priority with 
automobile dealerships. Journal of Organizational Behavior, 36(3), 339-359. http://dx.doi:10.1002/job.1985

Braddy, P. W., Meade, A. W., \& Kroustalis, C. M. (2006). Organizational recruitment website Effects on viewers' perceptions of organizational culture. Journal of Business and Psychology, 20(4), 525-543. http://dx.doi:10.1007/s 10869-005-9003-

Cameron, K., \& Quinn, R. (1999). Diagnosing and changing organizational culture. Reading, MA: Addison-Wesley.

Campbell, T. C., Gallmeyer, M., Johnson, S. A., Rutherford, J., \& Stanley, B. W. (2011). CEO optimism and forced turnover. Journal of Financial Economics, 101(3), 695-712. http://dx.doi:10.1016/j.jfineco.2011.03.004

Carpenter, M. A., Geletkanycz, M. A., \& Sanders, W. G. (2004). Upper echelons research revisited: Antecedents, elements, and consequences of top management team composition. Journal of Management, 30(6), 749-778. http://dx.doi:10.1016/j.jm.2004.06.001

Chatman, J. A., Caldwell, D. F., O'Reilly, C. A., \& Doerr, B. (2014). Parsing organizational culture: How the norm for adaptability influences the relationship between culture consensus and financial performance in high technology firms. Journal of Organizational Behavior, 35(6), 785-808. http://dx.doi:10.1002/job.1928

Chatman, J. A., \& O’Reilly, C. A. (2016). Paradigm lost: Reinvigorating the study of organizational culture. Research in Organizational Behavior, 36, 199-224. http://dx.doi:10.1111/j.20448325.1990.tb00525

Chatterjee, A., \& Hambrick, D. C. (2007). It's all about me: Narcissistic chief executive officers and their effects on company strategy and performance. Administrative Science Quarterly, 52(3), 351-386. http://dx.doi:10.2189/asqu.52.3.351

Cooke, R. A., \& Szumal, J. L. (1993). Measuring normative beliefs and shared behavioral expectations in organizations: The reliability and validity of the Organizational Culture Inventory. Psychological Reports, 72(3_suppl), 1299-1330. 
Daly, J. P., Pouder, R. W., \& Kabanoff, B. (2004). The effects of initial differences in firms' espoused values on their postmerger performance. The Journal of Applied Behavioral Science, 40(3), 323-343. http://dx.doi:10.1177/0021886304266815

Davidson, R., Dey, A., \& Smith, A. (2015). Executives' “off-the-job” behavior, corporate culture, and financial reporting risk. Journal of Financial Economics, 117(1), 5-28. http://dx.doi:10.1016/j.jfineco.2013.07.004

Denison, D. (1996). What is the difference between organizational culture and organizational climate? A native's point of view on a decade of paradigm wars. Academy of Management Review, 21(3), 619-654. http://dx.doi:10.5465/amr.1996.9702100310

Denison, D., Nieminen, L., \& Kotrba, L. (2014). Diagnosing organizational cultures: A conceptual and empirical review of culture effectiveness surveys. European Journal of Work and Organizational Psychology, 23(1), 145-161. http://dx.doi:10.1080/1359432X.2012.713173

Deshpandé, R., Farley, J. U., \& Webster Jr, F. E. (1993). Corporate culture, customer orientation, and innovativeness in Japanese firms: a quadrad analysis. The Journal of Marketing, 57(1), 23-37. http://dx.doi:10.2307/1252055

Di Giuli, A., \& Kostovetsky, L. (2014). Are red or blue companies more likely to go green? Politics and corporate social responsibility. Journal of Financial Economics, 111(1), 158-180. http://dx.doi:10.1016/j.jfineco.2013.10.002

Dobbin, F., Kim, S., \& Kalev, A. (2011). You can't always get what you need. American Sociological Review, 76(3), 386-411. http://dx.doi:10.1177/0003122411409704

Eliasoph, N., \& Lichterman, P. (2003). Culture in interaction. American Journal of Sociology, 108(4), 735-794.

Erwin, P. M. (2011). Corporate codes of conduct: The effects of code content and quality on ethical performance. Journal of Business Ethics, 99(4), 535-548. http://dx.doi:10.1007/s10551-0100667-y 
Farrell, A. (2015). Explaining leniency: Organizational predictors of the differential treatment of men and women in traffic stops. Crime \& Delinquency, 61(4), 509-537. http://dx.doi:10.1177/0011128711420108

Farrell, H., \& Farrell, B. J. (1998). The language of business codes of ethics: Implications of knowledge and power. Journal of Business Ethics, 17(6), 587-601. http://dx.doi:10.1023/A:1005749026983

Financial Conduct Authority. (2018). DP18/2: Transforming culture in financial services. FCA, London.

Fiordelisi, F., \& Ricci, O. (2014). Corporate culture and CEO turnover. Journal of Corporate Finance, 28, 66-82. http://dx.doi:10.1016/j.jcorpfin.2013.11.009

Giorgi, S., Lockwood, C., \& Glynn, M. A. (2015). The many faces of culture: Making sense of 30 years of research on culture in organization studies. The Academy of Management Annals, 9(1), 1-54. http://dx.doi.org/10.1080/19416520.2015.1007645

Gleibs, I. H. (2017). Are all "research fields" equal? Rethinking practice for the use of data from crowdsourcing market places. Behavior Research Methods, 49(4), 1333-1342. https://doi.org/10.3758/s13428-016-0789-y

Goldberg, A., Srivastava, S. B., Manian, V. G., Monroe, W., \& Potts, C. (2016). Fitting in or standing out? The tradeoffs of structural and cultural embeddedness. American Sociological Review, 81(6), 1190-1222. http://dx.doi:10.1177/0003122416671873

Hartnell, C., Ou, A. Y., \& Kinicki, A. (2011). Organizational culture and organizational effectiveness: a meta-analytic investigation of the competing values framework's theoretical suppositions. Journal of Applied Psychology, 96(4), 677-694. http://dx.doi:10.1037/a0021987

Haynes, S. N., Richard, D., \& Kubany, E. S. (1995). Content validity in psychological assessment: a functional approach to concepts and methods. Psychological Assessment, 7(3), 238.

Hill, A. D., White, M. A., \& Wallace, J. C. (2014). Unobtrusive measurement of psychological constructs in organizational research. Organizational Psychology Review, 4(2), 148-174. http://dx.doi:10.1177/2041386613505613 
Hofstede, G., Neuijen, B., Ohayv, D. D., \& Sanders, G. (1990). Measuring organizational cultures: A qualitative and quantitative study across twenty cases. Administrative Science Quarterly, 35(2), 286-316. https://doi.org/10.2307/2393392

Hoi, C. K., Wu, Q., \& Zhang, H. (2013). Is corporate social responsibility (CSR) associated with tax avoidance? Evidence from irresponsible CSR activities. The Accounting Review, 88(6), 20252059. http://dx.doi:10.2308/accr-50544

Hsu, G., \& Hannan, M. (2005). Identities, genres, and organizational forms. Organization Science, 16(5), 474-490. http://dx.doi:10.1287/orsc.1050.0151

Huang, M., Li, P., Meschke, F., \& Guthrie, J. P. (2015). Family firms, employee satisfaction, and corporate performance. Journal of Corporate Finance, 34, 108-127. http://dx.doi:10.1016/j.jcorpfin.2015.08.002

Hutton, I., Jiang, D., \& Kumar, A. (2015). Political values, culture, and corporate litigation. Management Science, 61(12), 2905-2925. http://dx.doi:10.1287/mnsc.2014.2106

Ji, Y., Rozenbaum, O., \& Welch, K. T. (2017). Corporate Culture and Financial Reporting Risk: Looking Through the Glassdoor. Social Science Research Network. http://dx.doi:10.2139/ssrn.2945745

Jung, T., Scott, T., Davies, H. T., Bower, P., Whalley, D., McNally, R., \& Mannion, R. (2009). Instruments for exploring organizational culture: A review of the literature. Public Administration Review, 69(6), 1087-1096. http://dx.doi:10.1111/j.1540-6210.2009.02066

Knight, A. P. (2018). Innovations in unobtrusive methods. In A. Bryman \& D. Buchanan (Eds.), Unconventional Methodology in Organization and Management Research (pp. 64-83). Oxford: Oxford University Press.

Kotrba, L. M., Gillespie, M. A., Schmidt, A. M., Smerek, R. E., Ritchie, S. A., \& Denison, D. R. (2012). Do consistent corporate cultures have better business performance? Exploring the interaction effects. Human Relations, 65(2), 241-262. http://dx.doi:10.1177/0018726711426352 
Kowalczyk, S. J., \& Pawlish, M. J. (2002). Corporate branding through external perception of organizational culture. Corporate Reputation Review, 5(2-1), 159-174.

Kulik, B. W. (2005). Agency theory, reasoning and culture at Enron: In search of a solution. Journal of Business Ethics, 59(4), 347-360. http://dx.doi:10.1007/s10551-004-7308-2

Kummerow, K., \& Kirby, N. (2013). Organisational culture: Concept, context, and measurement. New York: World Scientific Press.

Lakoff, G. (1987). Women, fire, and dangerous things: What categories reveal about the mind. Cambridge: Cambridge University Press.

Lamont, M., \& Thevenot, L. (2000). Rethinking comparative cultural sociology. Cambridge: Cambridge University Press.

Leaver, M. P., \& Reader, T. W. (2017). Safety culture in financial trading: An analysis of trading misconduct investigations. Journal of Business Ethics. http://dx.doi:10.1007/s10551-017$3463-0$

Levi-Strauss, C. (1979). Myth and meaning. New York, NY: Schocken Books.

Loomis, D., \& Meyer, P. (2000). Opinion without polls: Finding a link between corporate culture and public journalism. International Journal of Public Opinion Research, 12(3), 276-284. http://dx.doi:10.1093/ijpor/12.3.276

Luciano, M. M., Mathieu, J. E., Park, S., \& Tannenbaum, S. I. (2018). A fitting approach to construct and measurement alignment: The role of big data in advancing dynamic theories. Organizational Research Methods, 21(3), 592-632. http://dx.doi:10.1177/1094428117728372

Martin, J. (1992). Cultures in organizations: Three perspectives: Sage, Thousand Oaks

McSweeney, B. (2002). Hofstede's model of national cultural differences and their consequences: A triumph of faith-a failure of analysis. Human Relations, 55(1), 89-118. http://dx.doi:10.1177/0018726702551004

Meek, V. L. (1988). Organizational culture: Origins and weaknesses. Organization Studies, 9(4), 453473. 
Mervis, C., \& Rosch, E. (1981). Categorization of natural objects. Annual Review of Psychology, $32(1), 89-115$.

Mescher, S., Kossek, E. E., Lewis, S., Hammer, L. B., Benschop, Y., \& Doorewaard, H. (2010). Representations of work-life balance support. Human Relations, 63(1), 21-39. http://dx.doi:10.1177/0018726709349197

Mills, J. (2005). Organizational change and representations of women in a North American utility company. Gender, Work \& Organization, 12(3), 242-269. http://dx.doi:10.1111/j.14680432.2005 .00272

Mitroff, I. I., \& Kilmann, R. H. (1976). On organization stories: An approach to the design and analysis of organizations through myths and stories. The Management of Organization Design, 1(189-207).

Moniz, A. (2015). Inferring employees' social media perceptions of goal-setting corporate cultures and the link to firm value. Unpublished Working Paper.

Morris, M. W., Leung, K., Ames, D., \& Lickel, B. (1999). Views from inside and outside: Integrating emic and etic insights about culture and justice judgment. Academy of Management Review, 24(4), 781-796. http://dx.doi:10.5465/amr.1999.2553253

Morrison, E. W., \& Milliken, F. J. (2000). Organizational silence: A barrier to change and development in a pluralistic world. Academy of Management Review, 25(4), 706-725. http://dx.doi:10.5465/amr.2000.3707697

O'Reilly, C. A., Chatman, J., \& Caldwell, D. F. (1991). People and organizational culture: A profile comparison approach to assessing person-organization fit. Academy of Management Journal, 34(3), 487-516.

Ostroff, C., Kinicki, A., \& Muhammad, R. (2012). Organizational culture and climate. In N. Schmitt \& S. Highhouse (Eds.), Handbook of Psychology. New York: John Wiley and Sons.

Ouchi, W. G., \& Wilkins, A. L. (1985). Organizational culture. Annual Review of Sociology, 11(1), 457-483. http://dx.doi:10.1146/annurev.so.11.080185.002325 
Park, G., Schwartz, H. A., Eichstaedt, J. C., Kern, M. L., Kosinski, M., Stillwell, D. J., . . Seligman, M. E. (2015). Automatic personality assessment through social media language. Journal of Personality and Social Psychology, 108(6), 934-952. http://dx.doi:10.1037/pspp0000020

Paté-Cornell, M. E. (1993). Learning from the piper alpha accident: A postmortem analysis of technical and organizational factors. Risk Analysis, 13(2), 215-232.

Popadak, J. A. (2013). A corporate culture channel: How increased shareholder governance reduces firm value. Social Science Research Network. Retrieved from https://ssrn.com/abstract=2345384 http://dx.doi:10.2139/ssrn.2345384

Putnam, R. D., Leonardi, R., \& Nanetti, R. Y. (1994). Making democracy work: Civic traditions in modern Italy. Princeton, New Jersey: Princeton University Press.

Rao, H., \& Giorgi, S. (2006). Code breaking: How entrepreneurs exploit cultural logics to generate institutional change. In B. Staw (Ed.), Research in Organizational Behavior (Vol. 27, pp. 269-304). Greenwich, CT: JAI Press.

Schein, E. (1984). Coming to a new awareness of organizational culture. Sloan Management Review, 25(2), 3-16.

Schein, E. (1992). Organizational Culture and Leadership. San Francisco, CA.: Jossey-Bass.

Schein, E. (1999). The Corporate Culture Survival Guide. San Francisco: John Wiley \& sons.

Schneider, B., Ehrhart, M. G., \& Macey, W. H. (2013). Organizational climate and culture. Annual Review of Psychology, 64, 361-388. http://dx.doi:10.1146/annurev-psych-113011-143809

Sechrest, L., \& Phillips, M. (1979). Unobtrusive measures: An overview. In L. Sechrest (Ed.), New directions for methodology of behavioral science. San Francisco, CA: Jossey-Bass, Inc.

Short, J. C., McKenny, A. F., \& Reid, S. W. (2018). More than words? Computer-aided text analysis in organizational behavior and psychology research. Annual Review of Organizational Psychology and Organizational Behavior, 5, 415-435. http://dx.doi:10.1146/annurevorgpsych-032117-104622 
Short, J. C., \& Palmer, T. B. (2008). The application of DICTION to content analysis research in strategic management. Organizational Research Methods, 11(4), 727-752. http://dx.doi:10.1177/1094428107304534

Srivastava, S. B., Goldberg, A., Manian, V. G., \& Potts, C. (2017). Enculturation trajectories: Language, cultural adaptation, and individual outcomes in organizations. Management Science, 64(3), 1348-1364. http://dx.doi:10.1287/mnsc.2016.2671

Suchan, J., \& Scott, C. (1986). Unclear contract language and its effect on corporate culture. Business Horizons, 29(1), 20-25.

Sullivan, J. L., Shwartz, M., Burgess Jr, J. F., Peköz, E. A., Christiansen, C. L., Gerena-Melia, M., \& Berlowitz, D. (2013). Person-centered care practices and quality in Department of Veterans Affairs nursing homes: Is there a relationship? Medical Care, 51(2), 165-171. http://dx.doi:10.1097/MLR.0b013e3182763230

Suzuki, S. (2013). Culture change in organizational public discourse 1998-2008: Examining annual reports of Japanese and US corporations. International Journal of Intercultural Relations, 37(5), 579-593. http://dx.doi:10.1016/j.jiintrel.2013.06.002

Swales, J. M., \& Rogers, P. S. (1995). Discourse and the projection of corporate culture: The mission statement. Discourse \& Society, 6(2), 223-242. http://dx.doi:10.1177/0957926595006002005

Tate, G., \& Yang, L. (2015). Female leadership and gender equity: Evidence from plant closure. Journal of Financial Economics, 117(1), 77-97. http://dx.doi:10.1016/j.jfineco.2014.01.004

Thelwall, M., \& Buckley, K. (2013). Topic-based sentiment analysis for the social web: The role of mood and issue-related words. Journal of the American Society for Information Science and Technology, 64(8), 1608-1617. https://doi.org/10.1002/asi.22872

Tonidandel, S., King, E. B., \& Cortina, J. M. (2018). Big Data methods: Leveraging modern data analytic techniques to build organizational science. Organizational Research Methods, 21(3), 525-547. http://dx.doi:10.1177/1094428116677299 
Tsui, A. S., Zhang, Z.-X., Wang, H., Xin, K. R., \& Wu, J. B. (2006). Unpacking the relationship between CEO leadership behavior and organizational culture. The Leadership Quarterly, 17(2), 113-137.

Van den Berg, P. T., \& Wilderom, C. P. (2004). Defining, measuring, and comparing organisational cultures. Applied Psychology, 53(4), 570-582. http://dx.doi:10.1111/j.14640597.2004.00189.x

Vaughan, D. (1999). The dark side of organizations: Mistake, misconduct, and disaster. Annual Review of Sociology, 25(1), 271-305. http://dx.doi:10.1146/annurev.soc.25.1.271

Verbeke, W., Volgering, M., \& Hessels, M. (1998). Exploring the conceptual expansion within the field of organizational behaviour: Organizational climate and organizational culture. Journal of Management Studies, 35(3), 303-329. http://dx.doi:10.1111/1467-6486.00095

Webb, E., Campbell, D. T., Schwartz, R. D., \& Sechrest, L. (1966). Unobtrusive measures: Nonreactive research in the social sciences: Rand McNally, Chicago.

Webb, E., \& Weick, K. E. (1979). Unobtrusive measures in organizational theory: A reminder. Administrative Science Quarterly, 24(4), 650-659.

Westrum, R. (2004). A typology of organisational cultures. Quality and Safety in Health Care, 13(suppl 2), ii22-ii27. http://dx.doi:10.1136/qshc.2003.009522

Williams, M. R., \& Attaway, J. S. (1996). Exploring salespersons' customer orientation as a mediator of organizational culture's influence on buyer-seller relationships. Journal of Personal Selling \& Sales Management, 16(4), 33-52.

Wilson, E. (2000). Inclusion, exclusion and ambiguity-The role of organisational culture. Personnel Review, 29(3), 274-303. http://dx.doi:10.1108/00483480010324652

Yarkoni, T., \& Westfall, J. (2017). Choosing prediction over explanation in psychology: Lessons from machine learning. Perspectives on Psychological Science, 12(6), 1100-1122.

Zuber, F., \& Kaptein, M. (2014). Painting with the same brush? Surveying unethical behavior in the workplace using self-reports and observer-reports. Journal of Business Ethics, 125(3), 401432. http://dx.doi:10.1007/s10551-013-1920-y 


\section{Stage 1: Initial Search}

Electronic search: PsycINFO, Web of Science

Search term: "organi\#ational culture" OR "work-unit culture" OR "department culture" OR "work-team culture" OR "work culture" OR "corporate culture" in the abstract

Limitations: Articles in English, empirical study, peer reviewed

Results: 3,184 articles

\section{Stage 2: Screening of results}

Filter: Titles examined for initial relevance. Abstracts were examined to assess whether methodology was explicitly mentioned, and whether the paper reported empirical data

Exclusion criteria: Articles did not mention any specific methods in title or abstract

Inclusion criteria: Articles explicitly mentioned specific methods in their title or abstract

Results: 2,060 articles

\section{Stage 3: Article categorization}

Filter: Titles and abstracts were read in order to establish whether an internal-reactive metric was used Exclusion criteria: Unless an alternative methodology was reported, articles using the following methods were removed: 'Survey/questionnaire with organizational members', 'interview/focus group with organizational members', 'organizational member vignettes', 'observations of behaviour (overt)', 'case study', and 'other (e.g., action research)'

Results: 178 articles

\section{Stage 4: Final article selection}

Filter: Articles were read entirely

Inclusion criteria I: The article reported empirical data from an unobtrusive data source Inclusion criteria II: The aspect of organizational culture being measured by an unobtrusive source was described

$\underline{\text { Results: }} 35$ articles

Figure 1. Study identification procedure. 
Table 1. Key coding categories

\begin{tabular}{|c|c|}
\hline Coding framework & Description \\
\hline \multicolumn{2}{|l|}{ Data source characteristics } \\
\hline Unobtrusive data source & Data collected without directly engaging organizational members \\
\hline Internal & Data produced within an organization (e.g., reports, employee data) \\
\hline External & Data produced outside an organization (e.g., social media, customer ratings) \\
\hline \multicolumn{2}{|l|}{ OCP dimensions } \\
\hline Adaptability & $\begin{array}{l}\text { Innovative; experimental; fast-moving; quick to take advantage of } \\
\text { opportunities; adaptable }\end{array}$ \\
\hline Collaboration & Collaborative; team-oriented; cooperative; supportive; avoiding conflict \\
\hline Customer orientation & Listening to customers; being market driven, customer-oriented \\
\hline Detail orientation & Being precise; paying attend to detail; emphasising quality \\
\hline Integrity & Having integrity; being fair; high ethical standards; honesty; \\
\hline Results orientation & Being results-oriented; high performance expectations; achievement oriented; \\
\hline CVF dimensions & \\
\hline Clan & $\begin{array}{l}\text { Focus on people and human affiliation, indicated by teamwork, participation, } \\
\text { employee involvement, and open communication. }\end{array}$ \\
\hline Adhocracy & $\begin{array}{l}\text { Focus on growth and change, indicated by risk taking, creativity, and } \\
\text { adaptability }\end{array}$ \\
\hline Market & $\begin{array}{l}\text { Focus on competition and achievement, indicated by goal setting, planning, } \\
\text { task focus, and competitiveness, and rewards }\end{array}$ \\
\hline Hierarchy & $\begin{array}{l}\text { Focus on ensuring organizational structure, indicated by procedures, rules, } \\
\text { conformity, and predictability }\end{array}$ \\
\hline UIC validity as a culture & A UIC provides insight on the shared values, experiences or priorities for an \\
\hline indicator & organizational group (e.g., a team, unit, or entire company). \\
\hline UIC construct validity & $\begin{array}{l}\text { A UIC has data showing its measurement validity (e.g., reliability, } \\
\text { discriminant validity, convergent validity) or criterion validity. }\end{array}$ \\
\hline
\end{tabular}




\begin{tabular}{|c|c|c|c|c|c|}
\hline $\begin{array}{l}\text { Steps 1-3. Unobtrusive } \\
\text { indicator of culture } \\
\text { identified }\end{array}$ & $\begin{array}{l}\text { Step 4. UIC classified as } \\
\text { measuring employee or } \\
\text { managerial values, and } \\
\text { externally produced }\end{array}$ & $\begin{array}{l}\text { Step 5. UIC evaluated as } \\
\text { indicating content } \\
\text { relating to the OCP, CVF, } \\
\text { or another framework }\end{array}$ & $\begin{array}{l}\text { Step 6. UIC evaluated for } \\
\text { their validity as culture } \\
\text { indicators (shared values } \\
\text { within an organization) }\end{array}$ & $\begin{array}{c}\text { Step 7. UIC evaluated for } \\
\text { data on construct validity } \\
\text { (measurement and } \\
\text { outcome data) }\end{array}$ & Final UIC evaluation \\
\hline $\begin{array}{c}\text { Source: Employee online } \\
\text { assessments } \\
\text { Data: Presence of language } \\
\text { on goal setting } \\
\text { Indicates: Priority of goals }\end{array}$ & $\begin{array}{c}\text { Measures employee values } \\
\text { (as uses reports from } \\
\text { employees) and is externally } \\
\text { produced (anonymous } \\
\text { website) }\end{array}$ & $\begin{array}{c}\text { Coded as: results-orientation } \\
\text { (OCP) and market (CVF) due } \\
\text { to focus upon goals and } \\
\text { achievement }\end{array}$ & $\begin{array}{l}\text { Assesses shared values (as } \\
\text { captures reports of values } \\
\text { and experiences from } \\
\text { employees across the firm) }\end{array}$ & $\begin{array}{l}\text { Data on measurement } \\
\text { properties (e.g., language } \\
\text { models) available, and } \\
\text { associations with outcome } \\
\text { data }\end{array}$ & $\rightarrow \begin{array}{c}\text { Good construct validity } \\
\text { (valid cultural indicator, } \\
\text { and measurement/ } \\
\text { outcomes data) }\end{array}$ \\
\hline $\begin{array}{l}\text { Source: Annual report(s) } \\
\text { Data: Greater presence of } \\
\text { language relating to } \\
\text { adaptability } \\
\text { Indicates: Adaptability values }\end{array}$ & $\begin{array}{l}\text { Measures management } \\
\text { values (as reflects position of } \\
\text { leadership) and is internally } \\
\text { produced (internal report) }\end{array}$ & $\begin{array}{c}\text { Coded as: adaptability (OCP) } \\
\text { and adhocracy (CVF) as } \\
\text { relates to adaptability and } \\
\text { innovation }\end{array}$ & $\begin{array}{l}\text { Assesses shared values (as } \\
\text { annual report distils and } \\
\text { represents values of } \\
\text { organizational leadership }\end{array}$ & $\begin{array}{l}\text { Data on measurement } \\
\text { properties (e.g., correlation } \\
\text { with employee measures), } \\
\text { but no criterion validity }\end{array}$ & $\rightarrow \begin{array}{c}\text { Promising construct } \\
\text { validity (valid cultural } \\
\text { indicator, measurement } \\
\text { data, no outcome data) }\end{array}$ \\
\hline $\begin{array}{l}\text { Source: Customer survey } \\
\text { Data: Positive views of } \\
\text { customer service } \\
\text { Indicates: Focus on } \\
\text { customers } \\
\end{array}$ & $\begin{array}{l}\text { Measures employee values } \\
\text { (as refers to salespersons) } \\
\text { and is externally produced } \\
\text { (from customer ratings) }\end{array}$ & \begin{tabular}{|c|} 
Coded as: Customer \\
orientation (OCP) and market \\
(CVF) as refers to \\
prioritization of customers
\end{tabular} & $\begin{array}{c}\text { Assesses shared values } \\
\text { (customer ratings provide } \\
\text { data on values for employees } \\
\text { across the organization) }\end{array}$ & $\begin{array}{l}\text { Data on measurement } \\
\text { properties (e.g., reliability), } \\
\text { but no outcome data is } \\
\text { available }\end{array}$ & $\rightarrow \begin{array}{c}\text { Promising construct } \\
\text { validity (valid cultural } \\
\text { indicator, measurement } \\
\text { data, no outcome data) }\end{array}$ \\
\hline $\begin{array}{c}\text { Source: Policies/code of } \\
\text { conduct } \\
\text { Data: Clear values on equal } \\
\text { opportunities } \\
\text { Indicates: Equality } \\
\end{array}$ & $\begin{array}{c}\text { Measures management } \\
\text { values (as reflects policy of } \\
\text { leadership) and is internally } \\
\text { produced (from internal } \\
\text { reports) }\end{array}$ & \begin{tabular}{|c|} 
Coded as: diversity (due to \\
focus on equal opportunities) \\
and as outside of the OCP \\
and CVF frameworks
\end{tabular} & $\begin{array}{l}\text { Assesses shared values (as } \\
\text { policy documents represent } \\
\text { values and priorities of } \\
\text { organizational leadership }\end{array}$ & $\begin{array}{l}\text { No data on measurement } \\
\text { properties or outcome data } \\
\text { is available }\end{array}$ & $\rightarrow \begin{array}{c}\text { Low construct validity } \\
\text { (valid cultural indicator, } \\
\text { no measurement/ } \\
\text { outcome data) }\end{array}$ \\
\hline $\begin{array}{l}\text { Source: Executive analytics } \\
\text { Data: Errors in financial } \\
\text { reporting } \\
\text { Indicates: Potentially } \\
\text { fraudulent practices }\end{array}$ & $\begin{array}{c}\text { Measures management } \\
\text { values (as relates to } \\
\text { executives) and is externally } \\
\text { produced (from a risk } \\
\text { database) }\end{array}$ & $\begin{array}{l}\text { Coded as: integrity (due to } \\
\text { focusing on dishonest } \\
\text { behavior) within the CVF } \\
\text { framework (not related to } \\
\text { the OCP) }\end{array}$ & $\begin{array}{c}\text { Does not assess shared } \\
\text { values (as mistakes may be } \\
\text { genuine, and unclear as to } \\
\text { who precisely is responsible } \\
\text { for errors) }\end{array}$ & $\begin{array}{l}\text { No data on measurement } \\
\text { properties, but association } \\
\text { with quality of financial } \\
\text { controls }\end{array}$ & $\rightarrow \quad \begin{array}{c}\text { No construct validity } \\
\text { (does not assess shared } \\
\text { values) }\end{array}$ \\
\hline $\begin{array}{l}\text { Source: Legal data } \\
\text { Data: Frequency of labor } \\
\text { litigation suits filed } \\
\text { Indicates: Employee } \\
\text { treatment }\end{array}$ & $\begin{array}{c}\text { Measures management } \\
\text { values (as relates to manager } \\
\text { decisions) and is externally } \\
\text { produced (from legal } \\
\text { database) }\end{array}$ & $\begin{array}{l}\text { Coded as: clan (refers to } \\
\text { treatment of employees) } \\
\text { within the CVF framework } \\
\text { (not related to the OCP) }\end{array}$ & $\begin{array}{c}\text { Does not assess shared } \\
\text { values (unclear whose values } \\
\text { are shared represented: e.g., } \\
\text { managers or plaintiff) }\end{array}$ & $\begin{array}{l}\text { No data on measurement } \\
\text { properties or outcome data } \\
\text { is available }\end{array}$ & $\rightarrow \begin{array}{c}\text { No construct validity } \\
\text { (does not assess shared } \\
\text { values) }\end{array}$ \\
\hline
\end{tabular}

Figure 2. The UIC codification process, with examples. 
Table 2. Articles identified in the review

\begin{tabular}{|c|c|c|c|c|c|c|}
\hline No. & Author & Year & Country & Industry & Data source & Culture model used \\
\hline 1 & $\begin{array}{l}\text { Ankney \& } \\
\text { Procopio }\end{array}$ & 2003 & USA & Media & $\begin{array}{l}\text { Employee records; } \\
\text { Organization publications; } \\
\text { Annual report(s) }\end{array}$ & Social responsibility \\
\hline 2 & Ball et al. & 2005 & USA & Mixed & $\begin{array}{l}\text { Organization websites; } \\
\text { Policies/code of conduct }\end{array}$ & Integration \\
\hline 3 & Barsade \& O'Neill & 2014 & USA & $\begin{array}{l}\text { Health } \\
\text { care }\end{array}$ & Patient/family survey & Compassion \\
\hline 4 & Biggerstaff et al. & 2015 & USA & Mixed & Executive analytics & Ethical \\
\hline 5 & Braddy et al. & 2006 & USA & Mixed & Organization website(s) & Organizational culture \\
\hline 6 & Chatman et al. & 2014 & Mixed & Tech & Annual report(s) & $\mathrm{OCP}$ \\
\hline 7 & Daly et al. & 2004 & USA & Mixed & Annual report(s) & Concern for employees \\
\hline 8 & Davidson et al. & 2015 & USA & Mixed & Executive analytics & Financial control \\
\hline 9 & Deshpandé et al. & 1993 & Japan & Mixed & Customer survey & Customer orientation \\
\hline 10 & $\begin{array}{l}\text { Di Giuli \& } \\
\text { Kostovetsky }\end{array}$ & 2014 & USA & Mixed & Executive analytics & Social responsibility \\
\hline 11 & Dobbin et al. & 2011 & USA & Mixed & Regulator data & Supporting diversity \\
\hline 12 & Duff et al. & 2015 & Canada & Services & Employee records & Absence \\
\hline 13 & Erwin & 2011 & USA & Mixed & Industry data & Ethical \\
\hline 14 & Farrell & 2015 & USA & Policing & Law enforcement data & Policing \\
\hline 15 & Farrell \& Farrell & 1998 & Australia & Mixed & Policies/code of conduct & Ethical \\
\hline 16 & Fiordelisi \& Ricci & 2014 & Italy & Mixed & Annual report(s) & $\begin{array}{l}\text { Competing values } \\
\text { framework }\end{array}$ \\
\hline 17 & Goldberg et al. & 2016 & USA & Tech & Employee emails & Organizational culture fit \\
\hline
\end{tabular}




\begin{tabular}{|c|c|c|c|c|c|c|}
\hline 18 & Hoi et al. & 2013 & USA & Mixed & Industry data & Social responsibility \\
\hline 19 & Huang et al. & 2015 & USA & Mixed & $\begin{array}{l}\text { Employees' online } \\
\text { assessments }\end{array}$ & Human-capital-enhancing \\
\hline 20 & Hutton et al. & 2015 & USA & Mixed & Legal data & Political \\
\hline 21 & Ji et al. & 2017 & USA & Mixed & Employees' online ratings & Corporate culture \\
\hline 22 & $\begin{array}{l}\text { Kowalczyk \& } \\
\text { Pawlish }\end{array}$ & 2002 & USA & Tech & Industry expert surveys & OCP \\
\hline 23 & Loomis \& Meyer & 2000 & USA & Media & Annual report(s) & Corporate culture \\
\hline 24 & Mescher et al. & 2010 & Holland & Mixed & Organization website(s) & Work-life balance \\
\hline 25 & Mills & 2005 & Canada & Electric & Annual report(s) & Gendered \\
\hline 26 & Moniz & 2015 & USA & Mixed & $\begin{array}{l}\text { Employees' online } \\
\text { assessments }\end{array}$ & Performance oriented \\
\hline 27 & Popadak & 2013 & USA & Mixed & $\begin{array}{l}\text { Employees' online } \\
\text { assessments }\end{array}$ & OCP \\
\hline 28 & Srivastava et al. & 2017 & USA & Tech & Employee emails & Organizational culture fit \\
\hline 29 & Suchan \& Scott & 1986 & USA & Mixed & Contracts & Corporate culture \\
\hline 30 & Sullivan, et al. & 2013 & USA & $\begin{array}{l}\text { Health } \\
\text { care }\end{array}$ & Performance & Person centered care \\
\hline 31 & Suzuki & 2013 & Japan & Mixed & Annual report(s) & Organizational culture \\
\hline 32 & Swales \& Rogers & 1995 & USA & Mixed & Mission statement(s) & Corporate culture \\
\hline 33 & Tate \& Yang & 2015 & USA & Mixed & Industry data & Female friendly \\
\hline 34 & $\begin{array}{l}\text { Williams \& } \\
\text { Attaway }\end{array}$ & 1996 & USA & Mixed & Customer survey & Customer orientation \\
\hline 35 & Wilson & 2000 & UK & Mixed & Policies/code of conduct & Gendered \\
\hline
\end{tabular}


Table 3. Unobtrusive data sources identified through the systematic review

\begin{tabular}{|c|c|c|c|c|c|c|}
\hline Data source & Description & $\begin{array}{c}\text { No. of } \\
\text { Articles (No. } \\
\text { of UICs) }\end{array}$ & $\begin{array}{l}\text { Internal / } \\
\text { External }\end{array}$ & Culture model(s) examined & $\begin{array}{c}\text { Group } \\
\text { measured }\end{array}$ & $\begin{array}{l}\text { UICs with promising } \\
\text { or good construct } \\
\text { validity }\end{array}$ \\
\hline $\begin{array}{l}\text { Annual } \\
\text { report(s) }\end{array}$ & $\begin{array}{l}\text { A company's report on its activities } \\
\text { for the past year }\end{array}$ & $7(15)$ & Internal & $\begin{array}{l}\text { Social responsibility; concern for } \\
\text { employees; diversity; competing } \\
\text { values framework; gendered }\end{array}$ & Management & 10 \\
\hline Industry data & $\begin{array}{l}\text { Industry rankings or assessment of } \\
\text { corporate activities }\end{array}$ & $6(11)$ & External & $\begin{array}{l}\text { Social responsibility; ethical; } \\
\text { female friendly }\end{array}$ & $\begin{array}{l}\text { Management \& } \\
\text { regulators }\end{array}$ & 7 \\
\hline $\begin{array}{l}\text { Employee } \\
\text { online } \\
\text { assessments }\end{array}$ & $\begin{array}{l}\text { Employee online comments or } \\
\text { ratings of their organization }\end{array}$ & $5(22)$ & External & $\begin{array}{l}\text { Human-capital-enhancing; } \\
\text { corporate culture; performance } \\
\text { orientation; organizational culture } \\
\text { profile }\end{array}$ & Employees & 19 \\
\hline $\begin{array}{l}\text { Policies/code } \\
\text { of conduct }\end{array}$ & $\begin{array}{l}\text { Policies and rules for setting } \\
\text { organizational standards }\end{array}$ & $5(21)$ & Internal & Diversity; ethical; gendered & Management & 6 \\
\hline $\begin{array}{l}\text { Executive } \\
\text { analytics }\end{array}$ & $\begin{array}{l}\text { Public data on organizational } \\
\text { leaders (e.g., rewards) }\end{array}$ & $5(19)$ & External & $\begin{array}{l}\text { Ethical; financial control; social } \\
\text { responsibility; political }\end{array}$ & Management & 6 \\
\hline $\begin{array}{l}\text { Organization } \\
\text { website(s) }\end{array}$ & $\begin{array}{l}\text { Webpages relating to an } \\
\text { organizations purpose/services }\end{array}$ & $3(14)$ & Internal & $\begin{array}{c}\text { Integration; organizational culture; } \\
\text { work-life balance }\end{array}$ & Management & 8 \\
\hline
\end{tabular}




\begin{tabular}{|c|c|c|c|c|c|c|}
\hline $\begin{array}{l}\text { Customer } \\
\text { survey }\end{array}$ & $\begin{array}{l}\text { Surveys of customer observations } \\
\text { about an organization }\end{array}$ & $3(3)$ & External & Compassion; customer orientation & Employees & 2 \\
\hline $\begin{array}{l}\text { Employee } \\
\text { records }\end{array}$ & $\begin{array}{l}\text { Details on the demography and } \\
\text { performance of employees }\end{array}$ & $3(3)$ & Internal & $\begin{array}{l}\text { Social responsibility; absence; } \\
\text { policing }\end{array}$ & Employees & 0 \\
\hline Legal data & $\begin{array}{l}\text { Legal cases against an } \\
\text { organization }\end{array}$ & $2(6)$ & External & Diversity; political & $\begin{array}{c}\text { Entire } \\
\text { organization }\end{array}$ & 0 \\
\hline Performance & Employee practices at work & $2(6)$ & Internal & Policing; person-centred care & Employees & 0 \\
\hline $\begin{array}{l}\text { Employee } \\
\text { emails }\end{array}$ & Employee communications & $2(2)$ & Internal & Organizational culture fit & Employees & 2 \\
\hline $\begin{array}{l}\text { Industry } \\
\text { expert surveys }\end{array}$ & $\begin{array}{l}\text { Expert observations on } \\
\text { organizational culture }\end{array}$ & $1(8)$ & External & Organizational culture profile & $\begin{array}{c}\text { Entire } \\
\text { organization }\end{array}$ & 2 \\
\hline Financial data & $\begin{array}{l}\text { Financial records for an } \\
\text { organization }\end{array}$ & $1(2)$ & Internal & Social responsibility & Management & 2 \\
\hline Contracts & $\begin{array}{l}\text { Legal agreements between } \\
\text { companies and their workforce }\end{array}$ & $1(1)$ & Internal & Corporate culture & Management & 0 \\
\hline $\begin{array}{l}\text { Mission } \\
\text { statement(s) }\end{array}$ & $\begin{array}{l}\text { Espoused values on an } \\
\text { organization's aims and values }\end{array}$ & $1(1)$ & Internal & Corporate culture & Management & 0 \\
\hline $\begin{array}{l}\text { Organization } \\
\text { publications }\end{array}$ & $\begin{array}{l}\text { Material published for public } \\
\text { information }\end{array}$ & $1(1)$ & Internal & Social responsibility & Management & 0 \\
\hline
\end{tabular}


Table 4. Number of UICs by culture dimension*, and level of construct validity for each

\begin{tabular}{|c|c|c|c|c|c|}
\hline & Total & Good & Promising & Low & None \\
\hline Adaptability/Adhocracy & 5 & 0 & 4 & 1 & 0 \\
\hline Clan & 17 & 3 & 6 & 3 & 5 \\
\hline Collaboration/Clan & 17 & 4 & 5 & 2 & 6 \\
\hline $\begin{array}{l}\text { Customer } \\
\text { orientation/Market }\end{array}$ & 9 & 1 & 2 & 0 & 6 \\
\hline Detail orientation & 3 & 0 & 3 & 0 & 0 \\
\hline Diversity & 17 & 0 & 1 & 7 & 9 \\
\hline Hierarchy & 5 & 0 & 1 & 0 & 4 \\
\hline Integrity & 38 & 0 & 14 & 2 & 22 \\
\hline Integrity/Hierarchy & 4 & 0 & 3 & 0 & 1 \\
\hline Results/Hierarchy & 4 & 0 & 3 & 0 & 1 \\
\hline Results/Market & 16 & 4 & 10 & 2 & 0 \\
\hline Total & 135 & 12 & 52 & 17 & 54 \\
\hline
\end{tabular}


Table 5. Example UICs evaluated as having good construct validity

\begin{tabular}{|c|c|c|c|c|c|}
\hline Data source & Data point & Indicates: & Dimension & Measurement evaluation & Outcomes \\
\hline Annual report(s) & $\begin{array}{l}\text { More references to } \\
\text { "competition" } 7\end{array}$ & $\begin{array}{l}\text { Importance of productivity to leaders and } \\
\text { decision-makers }\end{array}$ & Results/Market & Cluster analysis & $\begin{array}{l}\text { Post-acquisition } \\
\text { performance (ROA) }\end{array}$ \\
\hline Employee emails & $\begin{array}{l}\text { Similarity of language in } \\
\text { interactions }^{28}\end{array}$ & Sharedness of values between employees & $\begin{array}{l}\text { Collaboration/ } \\
\text { Clan }\end{array}$ & $\begin{array}{l}\text { Backward selection } \\
\text { analysis to identify } \\
\text { language categories }\end{array}$ & $\begin{array}{l}\text { Employee attainment, } \\
\text { involuntary exit }\end{array}$ \\
\hline $\begin{array}{l}\text { Employee online } \\
\text { assessments }\end{array}$ & $\begin{array}{l}\text { Higher employee ratings } \\
\text { on work/life balance }{ }^{19}\end{array}$ & $\begin{array}{l}\text { Employee experiences and perceptions of } \\
\text { values towards work-life balance }\end{array}$ & Clan & Convergent validity & Tobin's Q \\
\hline $\begin{array}{l}\text { Employee online } \\
\text { assessments }\end{array}$ & $\begin{array}{l}\text { Higher culture and values } \\
\text { rating score }\end{array}$ & $\begin{array}{l}\text { Employee experiences and perceptions of } \\
\text { a collaborative working environment }\end{array}$ & $\begin{array}{l}\text { Collaboration/ } \\
\text { Clan }\end{array}$ & $\begin{array}{l}\text { Differential correlations } \\
\text { with outcome variables }\end{array}$ & Fraud enforcements \\
\hline Employee online & Greater presence of & Employee experiences and perceptions of & Results/Market & Topic modelling & Multiple, including future \\
\hline assessments & $\begin{array}{l}\text { language relating to goal } \\
\text { setting }{ }^{26}\end{array}$ & values towards importance of goals & & algorithm & firm value and ROA \\
\hline $\begin{array}{l}\text { Employee online } \\
\text { assessments }\end{array}$ & $\begin{array}{l}\text { Greater presence of } \\
\text { language relating to } \\
\text { results orientation }{ }^{27}\end{array}$ & $\begin{array}{l}\text { Employee experiences and perceptions of } \\
\text { values towards importance of results }\end{array}$ & Results/Market & $\begin{array}{l}\text { Principle component } \\
\text { analysis }\end{array}$ & $\begin{array}{l}\text { Short-horizon equity } \\
\text { funds }\end{array}$ \\
\hline
\end{tabular}

Note. Superscript numbers refer to the article (in Table 1) from which the UIC was extracted.

Table 6 
Example UICs evaluated as having promising construct validity

\begin{tabular}{|c|c|c|c|c|c|}
\hline Data source & Data point & Indicates & Dimension & Measurement evaluation & Outcomes \\
\hline Annual report(s) & $\begin{array}{l}\text { Greater frequency of } \\
\text { words related to } \\
\text { performance }^{31}\end{array}$ & $\begin{array}{l}\text { Importance of performance to } \\
\text { leaders and decision-makers }\end{array}$ & $\begin{array}{l}\text { Results orientation/ } \\
\text { Market }\end{array}$ & $\begin{array}{l}\text { Exploratory factor } \\
\text { analysis and reliability } \\
\text { testing }\end{array}$ & - \\
\hline Customer survey & $\begin{array}{l}\text { Positive perceptions of } \\
\text { customer-orientation }^{37}\end{array}$ & $\begin{array}{l}\text { Customer evaluations of values for } \\
\text { providing good service }\end{array}$ & $\begin{array}{l}\text { Customer orientation/ } \\
\text { Market }\end{array}$ & Reliability testing & - \\
\hline $\begin{array}{l}\text { Executive } \\
\text { analytics }\end{array}$ & $\begin{array}{l}\text { Better quality of internal } \\
\text { financial controls }{ }^{8}\end{array}$ & Quality of governance & Integrity/Hierarchy & - & Misstated financial data \\
\hline Financial data & $\begin{array}{l}\text { Absence of aggressive tax } \\
\text { avoidance practices }{ }^{18}\end{array}$ & Presence of ethical practices & Integrity/Market & - & $\mathrm{ROA}$ \\
\hline Organization & Aspects of websites most & Importance of diversity to decision- & Diversity & Content validity & - \\
\hline website(s) & $\begin{array}{l}\text { strongly associated with } \\
\text { diversity }{ }^{5}\end{array}$ & makers and content providers & & assessment & \\
\hline $\begin{array}{l}\text { Policies/code of } \\
\text { conduct }\end{array}$ & $\begin{array}{l}\text { Includes ethics in } \\
\text { company mission } \\
\text { statement }^{13}\end{array}$ & $\begin{array}{l}\text { Values for ethical conduct held by } \\
\text { organizational decision-makers }\end{array}$ & Integrity & $\begin{array}{l}\text { Convergent validity with } \\
\text { CSR rankings }\end{array}$ & - \\
\hline
\end{tabular}

Note. Superscript numbers refer to the article (in Table 1) from which the UIC was extracted. 
Table 7. Example UICs evaluated as having low construct validity, with potential suggestions for achieving this

\begin{tabular}{|c|c|c|c|c|c|}
\hline Data source & Data point & Indicates & Dimension & Potential measurement evaluation & Potential outcomes \\
\hline Annual report(s) & $\begin{array}{l}\text { Higher number of CEO } \\
\text { words on social } \\
\text { responsibility }{ }^{23}\end{array}$ & $\begin{array}{l}\text { Importance of social responsibility } \\
\text { to organizational leadership }\end{array}$ & Integrity & $\begin{array}{l}\text { Cluster or principle component } \\
\text { analysis with other dimensions of } \\
\text { culture }\end{array}$ & Scandals \\
\hline Annual report(s) & $\begin{array}{l}\text { Equality in images of men } \\
\text { and women in job roles } 25\end{array}$ & $\begin{array}{l}\text { Institutional values for not having } \\
\text { gender-related roles }\end{array}$ & Diversity & $\begin{array}{l}\text { Convergent validity with } \\
\text { employee online reviews }\end{array}$ & $\begin{array}{l}\text { Litigation for unequal } \\
\text { treatment }\end{array}$ \\
\hline $\begin{array}{l}\text { Industry expert } \\
\text { surveys }\end{array}$ & $\begin{array}{l}\text { Higher average expert rating } \\
\text { of company innovation }{ }^{22}\end{array}$ & $\begin{array}{l}\text { Industry evaluations of institutional } \\
\text { values for innovation }\end{array}$ & $\begin{array}{l}\text { Adaptability/ } \\
\text { Adhocracy }\end{array}$ & $\begin{array}{l}\text { Convergent validity with } \\
\text { employee online reviews }\end{array}$ & Number of patents \\
\hline $\begin{array}{l}\text { Mission } \\
\text { statement(s) }\end{array}$ & $\begin{array}{l}\text { Greater presence of } \\
\text { language on collaboration }{ }^{32}\end{array}$ & $\begin{array}{l}\text { Importance of collaboration to } \\
\text { organizational leadership }\end{array}$ & Collaboration & $\begin{array}{l}\text { Convergent validity with } \\
\text { employee online reviews }\end{array}$ & Employee turnover rates \\
\hline $\begin{array}{l}\text { Organization } \\
\text { website(s) }\end{array}$ & $\begin{array}{l}\text { Higher prevalence of } \\
\text { espoused support for work- } \\
\text { life balance }{ }^{24}\end{array}$ & $\begin{array}{l}\text { Importance of work/life balance to } \\
\text { management and content providers }\end{array}$ & Clan & $\begin{array}{l}\text { Convergent validity with policies } \\
\text { for work-life balance }\end{array}$ & $\begin{array}{l}\text { Employee absence rates, } \\
\text { or working with flexible } \\
\text { contracts }\end{array}$ \\
\hline $\begin{array}{l}\text { Policies/code of } \\
\text { conduct }\end{array}$ & $\begin{array}{l}\text { Clear values in relation to } \\
\text { equal opportunities }{ }^{35}\end{array}$ & $\begin{array}{l}\text { Managerial commitment to } \\
\text { equality }\end{array}$ & Diversity & $\begin{array}{l}\text { Convergent validity with policies } \\
\text { for supporting diversity }\end{array}$ & Promotion of diverse staff \\
\hline
\end{tabular}

Note. Superscript numbers refer to the article (in Table 1) from which the UIC was extracted. 